\title{
Illustrators of the New World. The Image in the Spanish Scientific Expeditions of the Enlightenment
}

\author{
Miguel Ángel Puig-Samper \\ Instituto de Historia, CCHS-CSIC, Madrid, Spain \\ e-mail: mpuig@orgc.csic.es
}

Received: 18 September 2012; Accepted: 15 October 2012; Published online: 8 January 2013

\begin{abstract}
In the Eighteenth Century, with the boom in the exploration of the Earth, most travellers and explorers had painters and illustrators at their sides who recorded their adventures, even their deaths, the exotic locations they visited, the aborigines, the landscapes or the strange creatures or plants that inhabited them. The presence of artists would increase in these types of exploration companies, sent by Spain, in order to recognise the natural resources and the imperial control of their territories. We take as a starting point Löfling's expedition, in which naturalist artists seek to comply with the requirements of the Linnaean classification system then, looking at the case of Francisco Requena, who cartographically represented the territory and drew the activities of his own expedition members along the boundaries with the Portuguese empire. Likewise, we analyze expeditions known as "Botanical" to the different viceroyalties, which attempted to transmit the American nature idealized in a few "types" that were drawn and recorded to make the new species and the wealth of the Empire known, until finally arriving at the expedition of Malaspina, in which there is a step towards the depiction of the imperial landscape.
\end{abstract}

KEYWORDS: Scientific artists; Löfling; Requena; Mutis; Ruiz; Sessé; Malaspina; Humboldt

Citation/Cómo citar este artículo: Puig-Samper, M.A. (2012) "Illustrators of the New World. The Image in the Spanish Scientific Expeditions of the Enlightenment". Culture \& History Digital Journal 1(2): m102. doi: http://dx.doi.org/10.3989/ chdj.2012.m102

RESUMEN: Ilustradores del Nuevo Mundo. La imagen en las expediciones científicas de la Ilustración.- En el siglo XVIII, con la explosión de la exploración de la Tierra, la mayoría de los viajeros y expedicionarios llevan a su lado a pintores y dibujantes que dejan constancia de sus aventuras, incluso de su muerte, de los lugares exóticos visitados, los aborígenes, el paisaje o las extrañas criaturas vegetales o animales que las habitan. La presencia de artistas irá incrementándose en este tipo de empresas de exploración enviadas por España para el reconocimiento de los recursos naturales y el control imperial de sus territorios. Tomamos como punto de partida la expedición de Löfling, en la que los dibujantes naturalistas buscan cumplir con los requisitos del sistema linneano de clasificación, pasando por el caso de Francisco de Requena, que representa el territorio cartográficamente y dibuja la actividad de los propios expedicionarios en los límites con el espacio imperial portugués. Asimismo analizamos las expediciones conocidas como "botánicas" a los diferentes virreinatos, que intentaban transportar la naturaleza americana idealizada en unos "tipos" que se dibujan y graban para dar a conocer las nuevas especies y la riqueza del imperio, hasta llegar a la expedición de Malaspina, en la que se da un paso hacia la representación del paisaje imperial.

PALABRAS CLAVE: artistas científicos; Löfling; Requena; Mutis; Ruiz; Sessé; Malaspina; Humboldt

Copyright: (C) 2012 CSIC. This is an open-access article distributed under the terms of the Creative Commons AttributionNon Commercial (by-nc) Spain 3.0 License, with the exception of figures 1 to 4 and figures 7 to 26, for which written permission of the copyright owners and/or other rights holders (such as publicity and/or privacy rights) is required for distribution, reproduction, or other use of protected items beyond that allowed by fair use or other statutory exemptions. 


\section{THE ADVENTURE OF THE SCIENTIFIC ARTISTS}

The link between artists and science has been well known since ancient times for the interest of the scientists, especially the naturalists, to depict the discovered world and to show it to all. In the Eighteenth Century, with the boom in the exploration of the Earth, most travellers and explorers had painters and illustrators at their sides to record their adventures; even their deaths, the exotic locations they visited, the aborigines, the landscapes or the strange creatures or plants that inhabited them. The main characters, Malaspina, Cook and La Perouse, counted skilled painters among their men who left images of these other worlds so distant from old Europe for posterity (Stafford, 1984; Quilley and Bonehill, 2004) (figure 1).

The many European courts boasted about their scientific discoveries, the collections of natural objects that would fill their cabinets of curiosities and their natural history, but also about their collections of scientific illustrations, their plates and prints, many of them coming from the scientific expeditions. As Mauricio Nieto said, these scientific art productions must have been enough to satisfy the monarchy, the aristocratic market and the most important naturalists of Europe (Nieto Olarte, 2000: 67).

In the case of Spain, since the Sixteenth Century drawings have been found relating to the Spanish expansion in America and their discoveries of the natural world. Armadillos, opossums, llamas, alligators and other strange creatures appear depicted together with fantastic beings from European medieval imagery and unknown plants such as the tobacco, the potato and the tomato.

In the Seventeenth Century, despite there being a stop in expeditions, we find Bernardo Cienfuegos's ${ }^{1}$ unpublished work 'The History of Plants', which was a scholarly synthesis of the known plant world with colour drawings. On one of the manuscript's first pages there appears chamorro wheat with many names synonymous with Gaspar Bauhin, Mathiolo, Brunsfelsio, Dodoneo, Valerius Cordo, Gesnero, Fuchs, Cesalpino, Trago, etc. Cienfuegos made a coloured drawing of wheat, basically as was his habit,

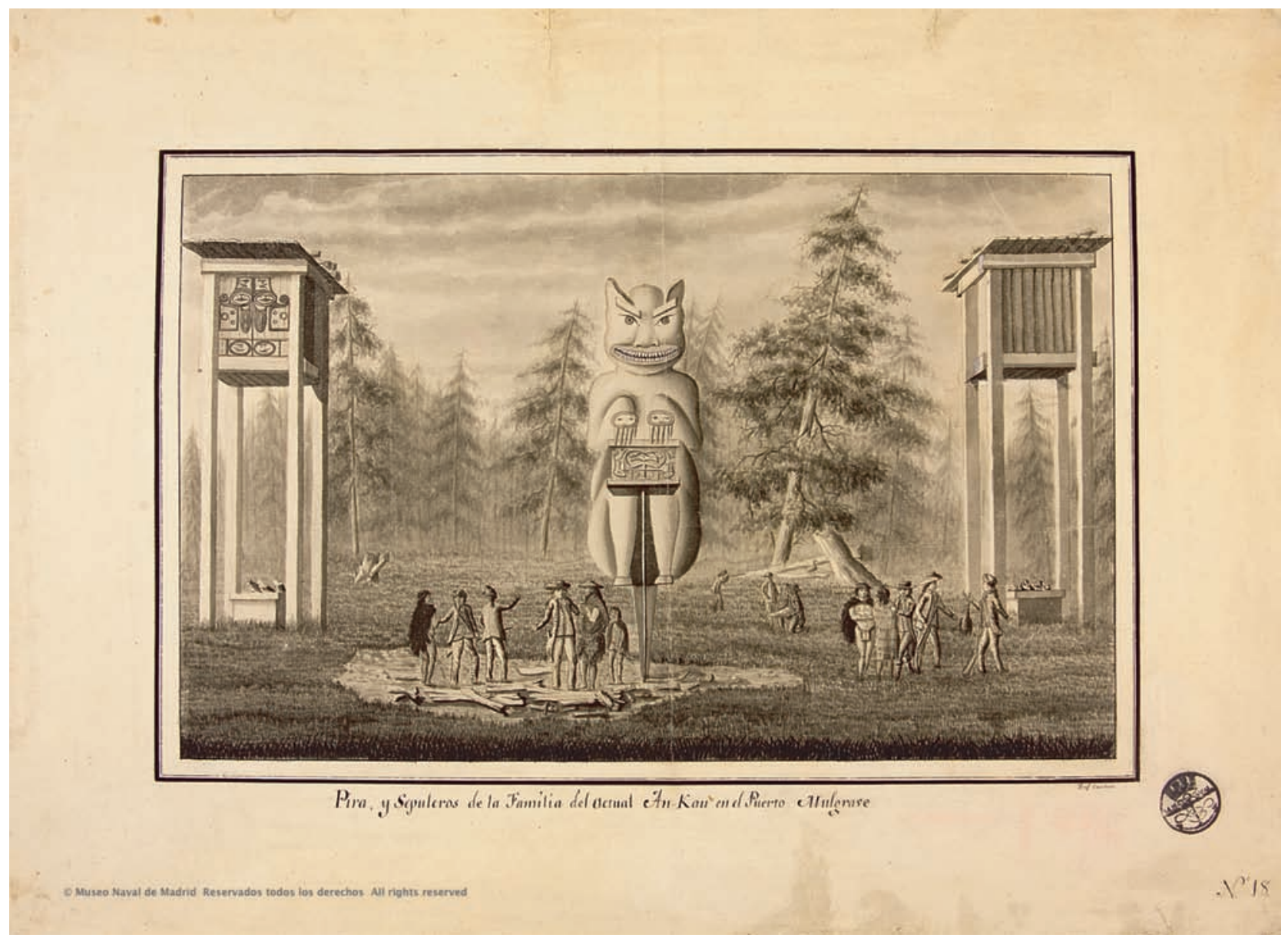

Figure 1. Mulgrave Harbour. José Cardero. Malaspina Expedition (1789-1794). Museo Naval, Madrid. 1723 (5). Reproduced with permission. 
highlighting the ears, stem, leaves and the root. The drawing gains valuable authority when Gesner used the drawing, giving it the name Triticum, something that was repeated by Fuchs as well as other authors, who used the same drawing. He used the drawing to differentiate botanical varieties, for example flax, concluding that the drawing was as essential as the descriptions written by authors such as Clusio and Mathias Lobel (figure 2).

With the arrival of the Enlightenment and the expeditions to the American territory, there would be an increase in the artists' presence. Already on the Iturriaga trip to the Orinoco, two artists accompanied the botanists in order to depict the plants they discovered according to the canons of the new science. It was necessary to draw not only the external aspect of the plant, but also as Linnaeus advised to take apart the sexual organs to see the number and how they were laid out, so as to be able to classify them. In the case of zoological iconography, Linnaeus mentioned in the various editions of 'Systema Naturae' that some authors

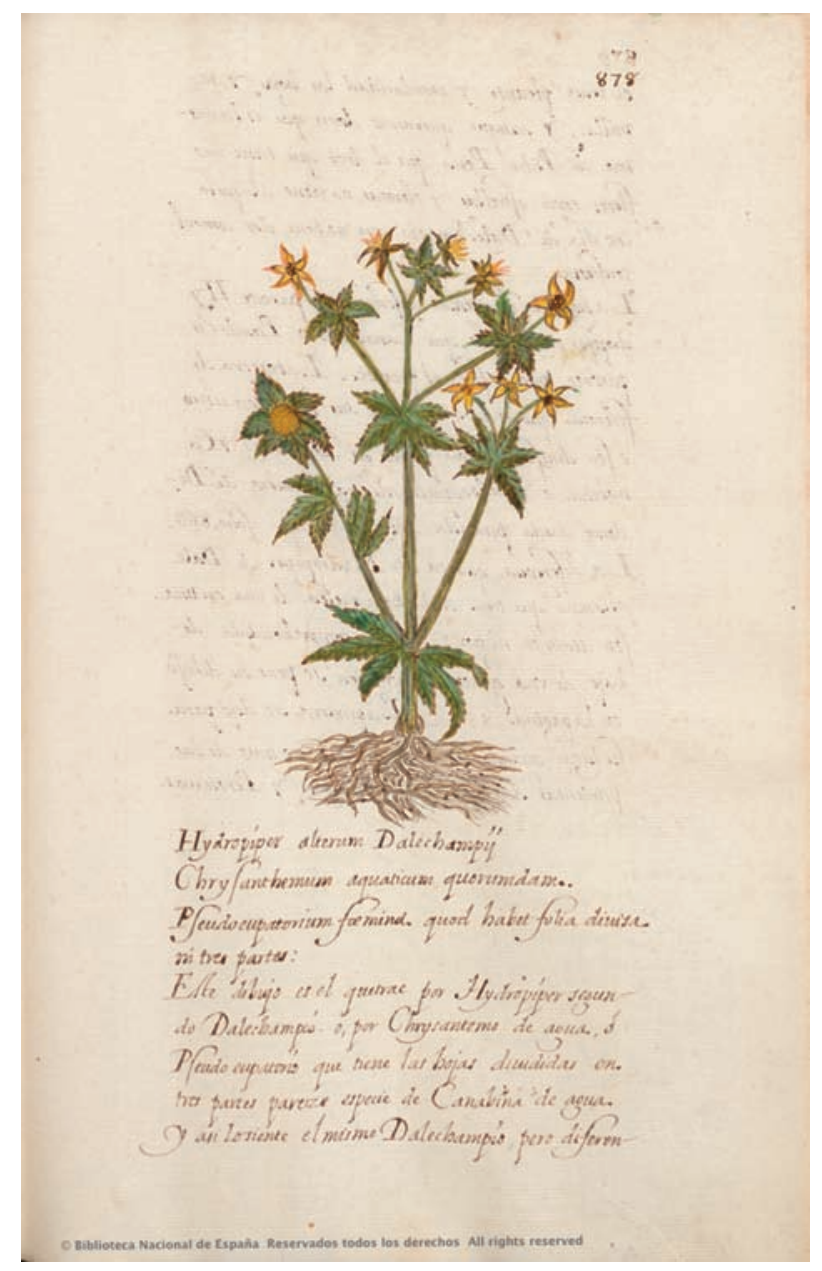

Figure 2. Hydropiper alterum Dalechampy. Bernardo de Cienfuegos, Historia de las Plantas. Biblioteca Nacional de España, ms. 3357. Reproduced with permission. were already recognized in its classification system such as Buanoni, Dezallier D'Angernville, Gualtieri for Malacology, Edwards and Frisch for Ornithology, Merian and Réaumur for Entomology and Catesby for Ichthyology, all were committed to a natural drawing that would assist taxonomic determination. A direction that would remain firm in the Enlightened Century and would only break to an extent with the Malaspina expedition and the subsequent theoretical appearance of Alexander von Humboldt's landscape painting (Blunt and Stearn, 1994; de Pedro, 1999).

In this work we will take a quick look at the work of these artist "scientists" who accompanied the cartographers and naturalists on their excursions in order to bear witness to what they saw. What those painters depicted, many of them trained in the Academies of Fine Arts, made the scientific descriptions credible.

\section{THE ROYAL ACADEMY OF FINE ARTS OF SAN FERNANDO}

In the opening address to the Royal Academy of Fine Arts of San Fernando, Alfonso Clemente de Arostegui, of the Royal Council of Castile, on the 13th of June 1752 pronounced:

\begin{abstract}
“. . Botany, that noble portion of Natural History, would it be so pleasant and appreciated if its images did not adorn design? It is true that if the Burin, the Brush and the Chisel withdraw their designs, models and prints for a day; since they most usefully instruct us, Sciences would remain silent or dead, when, on the contrary, animated by these noble instruments, the art of drawing shows the curious investigator what is contained within the great machine of the universe. And if not, tell me, when man sees so many varieties of plants and herbs, such a crowd of life that populates the different compositions of the land, the sea and the air, if the Drawing does not help him to imagine them? When or how could the vast spaces of sea and land be seen, measured, or walked if the Design, in a word the Map, has not captured them?... I think that this rough sketch of indescribable Design utilities is enough to prove the foundation of this Academy..." (Sotos Serrano, 1989: 71)
\end{abstract}

Two years later, in 1754, Tiburcio de Aguirre clearly marked the relationship between drawing and scientific progress:

\footnotetext{
"What art? What science could shine in its total independence from the drawing, lines, proportions, and models? What would become of anatomy? Without your help we would see the brightest light of Medicine extinguished in the tight delineations of even the smallest parts of the human structure. What about the Botany and Natural History? Naked and poorly weakened, deprived of prints and figures, which distinguish and depict the immense variety of species that glaze and beautify the extensive nature garden."
} 
Although as Jesusa Vega shows (Vega, 2011: 231), the author emphasised the supremacy of engraving above other arts, since neither science nor arts could excel it,

\begin{abstract}
"If the burin does not helps them, by multiplying the species almost at no cost, and spreading them throughout the globe; the lesser collection of prints, that today is a luxury trade in England, Holland, Venice and other Republics, include in its so many and so various depictions, all the amassed power of a sovereign and captured in Paintings and Statues in the most important Gallery.",2
\end{abstract}

\section{THE FIRST LINNAEAN ARTISTS}

In the mid-Eighteenth Century, the tension caused by the clash between the Spanish and Portuguese was about to cause a serious conflict in the South American arena. The foreign policy of Ferdinand VI, led by his minister Carvajal, attempted to solve the problem by signing, in 1750, the Treaty of Madrid, which recognized Spanish and Portuguese possessions in southern America. The Commission to set limits in the South was led by the Peruvian Commissioner Gaspar $\mathrm{Mu}$ nive, Marquis of Valdelirios. In order to carry out studies of the demarcation line in the North, the wellknown expedition was sent to the Orinoco, under the command of Captain José de Iturriaga. In addition, Eugenio Alvarado, Lieutenant Antonio de Urrutia and Sub-Lieutenant Jose Solano were appointed Commissioners of the expedition (Lucena Giraldo and de Pedro, 1992; Lucena Giraldo, 1991). In the Orinoco expedition team it should be noted that, among the mapmakers, instrument keepers, surgeons, and so on, was included an interesting group of naturalists Antonio Condal and Benito Paltor; scientific artists and Juan de Dios Castel and Bruno Salvador Carmona led by P. Loefling, the Swedish botanist who was a disciple of Linnaeus (Pelayo and Puig-Samper, 1992). It should not be forgotten that, although the expedition had the establishing of boundaries, the fight against smuggling and the containment of the Dutch as essential objectives, the Spanish Government already showed a special interest in the study of their territories' nature, both for its strategic and commercial as well as strictly scientific interest.

The two artists recruited for Löfling's expedition; the first strictly Linnean one, were prominent in the Registry of the Royal Academy of Fine Arts of San Fernando in Madrid, thereby launching interesting careers in the collaboration with the Spanish Expeditionary companies. We know that on the journey, the Spanish artists practiced naturalistic drawing under the Swedish botanist's guidance and made some experimental drawings of fish whilst aboard the Santa Ana. They later fully participated on Cumaná's excursions to the Orinoco and Guyana, Castel also participated in the expedition to the island of Trinidad with
Commissioner Iturriaga, where it is assumed he contributed to cartographic jobs, while Carmona assisted firstly Colonel Alvarado and later, Paltor (figure 3).

Löfling died in 1756 and his assistants deserted, so the work of natural history was interrupted for a long while. The expedition's scientific results were many drawings and botanical descriptions; which constituted 'Flora Cumanensis', later partially published by Linnaeus together with descriptions of Iberian flora in 'Iter Hispanicum', as well as zoological descriptions; although still not well studied, among which an 'Orinoco Ichtyologia' (figure 4) and a 'Medical Matter' of those regions stand out, all of them handwritten manuscripts. As for artistic results we can verify that they made 200 drawings, 95 signed by Carmona, 61 by Castel, while 44 were unsigned. Regarding their specialities; two maps, 115 botanical, 79 zoological and four ethnological drawings were preserved, which were a perfect demonstration of art in natural history, although it is necessary to comment that in the botanical drawings they still did not use the systematic anatomic dissections that we will see in later drawings of the Spanish expeditions, although in a few of them we see some detail. Also the use of colour was limited and remained in a classical style, although it is interesting how the drawings were

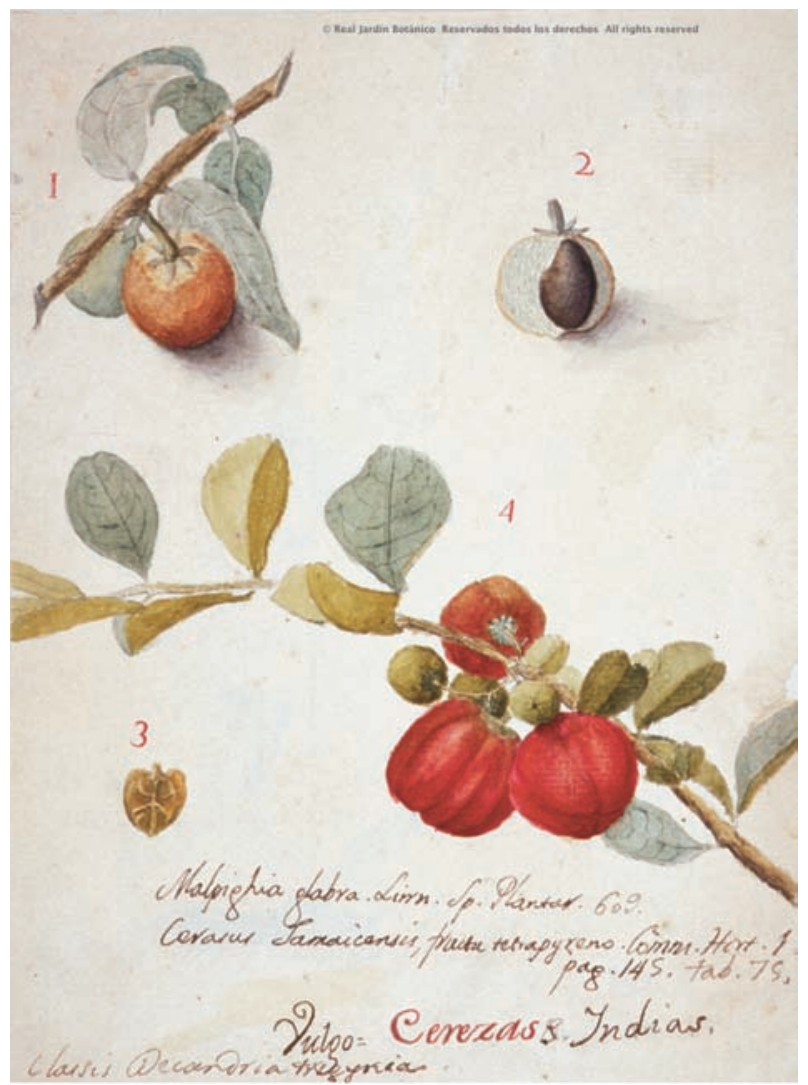

Figure 3. Malpighia glabra Linn. (West Indian Cherry). Pehr Löfling Commission to the Orinoco. Archivo del Real Jardín Botánico (CSIC), Madrid. Div. II, 30. Reproduced with permission. 
framed in that the plants themselves go beyond giving an interesting spatial sense.

On his return to the expedition, Castel was proposed as William Bowles' assistant, he was at first entrusted with the study of Löfling's work, following a request by the artists to continue working at the Madrid Royal Botanical Garden. ${ }^{3}$ In fact, it was Casimiro Gómez Ortega, the future designer of the botanical expeditions, who was finally assigned this job replacing Bowles, with him worked first Castel and then Bruno Salvador Carmona; as we know from the testimony of Cavanilles, who thought that Ortega was the reason for Löfling's iconographic objectives not being achieved (Cavanilles, 1801). This was basically devoted to noting the Orinoco expedition's drawings by trying to classify them with the help of the works of authors such as Linnaeus, Plukenet, Plumier, Sloane, Morison, Catesby, Jacquin, Aublet and so on; and the Löfling expedition was remembered by the Spanish naturalists as a model to follow, despite its relative failure.

\section{FRANCISCO REQUENA AND HIS SCENES OF THE EXPLORATION OF THE AMAZON}

In 1777, after a few years of continuous conflict along the Hispano-Lusitano borders as a result of the failure of the 1750 Boundary Treaty, the Spanish and Portuguese authorities; the former represented by the Count of Floridablanca and the latter by the Minister Francisco Inocencio Sousa Countinho, signed a new Boundary Treaty in San Ildefonso for their possessions in America and Asia. Part of it applied to the
Amazonian border of the two Imperial States, safeguarding the Portuguese establishments on the Japurá and Negro rivers and the Spanish in the Orinoco, as well as opening up the flow of communication (Lucena Giraldo, 1991b).

As had happened before, the responsibility of fixing the dividing lines fell to various Commissions, which were, in the Spanish case, set out in four administrative areas. The fourth was the Marañon Commission, organized in 1778, which was under the command of the Engineers Brigadier Francis de Requena (1743-1824). He left Quito in 1780 heading to the Amazon where he met the Portuguese a year later in the town of Tabatinga (Río Sadornil, 2003). The commissions, based in the town of Tefé, started their work in 1782 focussing especially on demarking the Japurá River. Requena reached the mouth of the Apaporis and the river known as los Engaños o el Yarí, however he never solved the dispute of the Western mouth of the Japurá and its access to the river Negro. Requena ended his Commission in 1791, returning to the governorship of Mainas, and two years later he went back to Spain where he became a member of the Council of the Indies and of the Council of State. As well as an impressive cartography that was carried out by Requena himself, a collection of watercolours has survived in the Committee at the Catholic University of Washington, (Oliveira Lima library) although there is no recognised signature we know that Requena refers many times to the artist Jose Anselmo Cartagena. The drawings show the Guayaquil River rafts; later better known from a similar drawing in Humboldt's works, a drawing

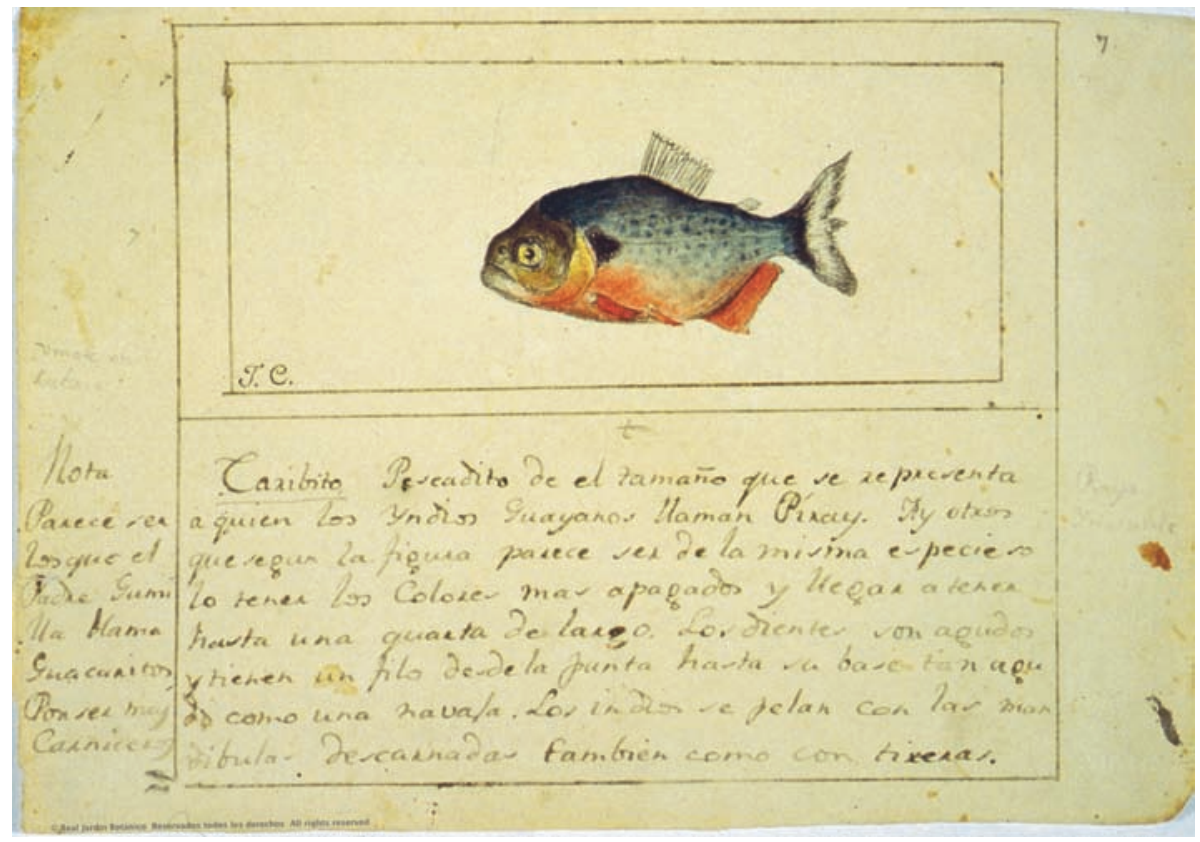

FIgure 4. Caribito. Juan de Dios Castel. Pehr Löfling Commission to the Orinoco. Archivo del Real Jardín Botánico (CSIC), Madrid. Div. II, 127. Reproduced with permission. 
explaining how to make a boat in the jungle by opening the trunk of trees, as well as a series of scenes where we see fights with the Amazonian Indians, the way of fishing, the different types of boats, the measurements of the engineers and mathematicians, the torrents or even Requena himself talking to indigenous people through an interpreter. In short, it is a jewel for understanding how the expedition moved and lived in the Amazon region in middle of Eighteenth Century (figure 5).

As for the cartographic work of Requena, Eric Beerman (Beerman, 1996) has noted a collection of eight maps of the Amazon region that are currently kept in the Library of Congress in Washington, which complement the Spanish collections and are also peculiar for being decorated with scenes that often show the Indigenous people in contrast to the European expeditionary members; man in a state of nature facing the enlightened and their rational world, something that years later we find in the Malaspina expedition.

If we stick to the expeditions aimed purely at knowledge of the New World's nature, the Royal Studio of Natural history and the Royal Botanical Garden of Madrid were in charge of carrying out the new plans, similar to what was happening in London and Paris. The expeditions and trips led by these institutions; especially by Casimiro Gómez Ortega the director of the Royal Botanical Garden, were commissioned, on one hand, to catalogue the three kingdoms of nature for its subsequent control and, on the other hand, to implement certain reforming measures in the colonies, especially for health and education. The ascendance to the throne of Charles III produced a greater effort to classify, from a scientific point of view, the nature of the New World (Puerto Sarmiento, 1988, 1992; Puig-Samper, 1991a; Lafuente and Sala Catalá, 1992; Puig-Samper and Pelayo, 1995; González Bueno and Rodríguez Nozal, 2000; López Piñero et al., 1983).

\section{THE IMPORTANCE OF DRAWING AND ENGRAVING FOR THE SPANISH BOTANISTS}

If we take a brief glance at the thought of the Spanish botanists of the Enlightenment, in the time of

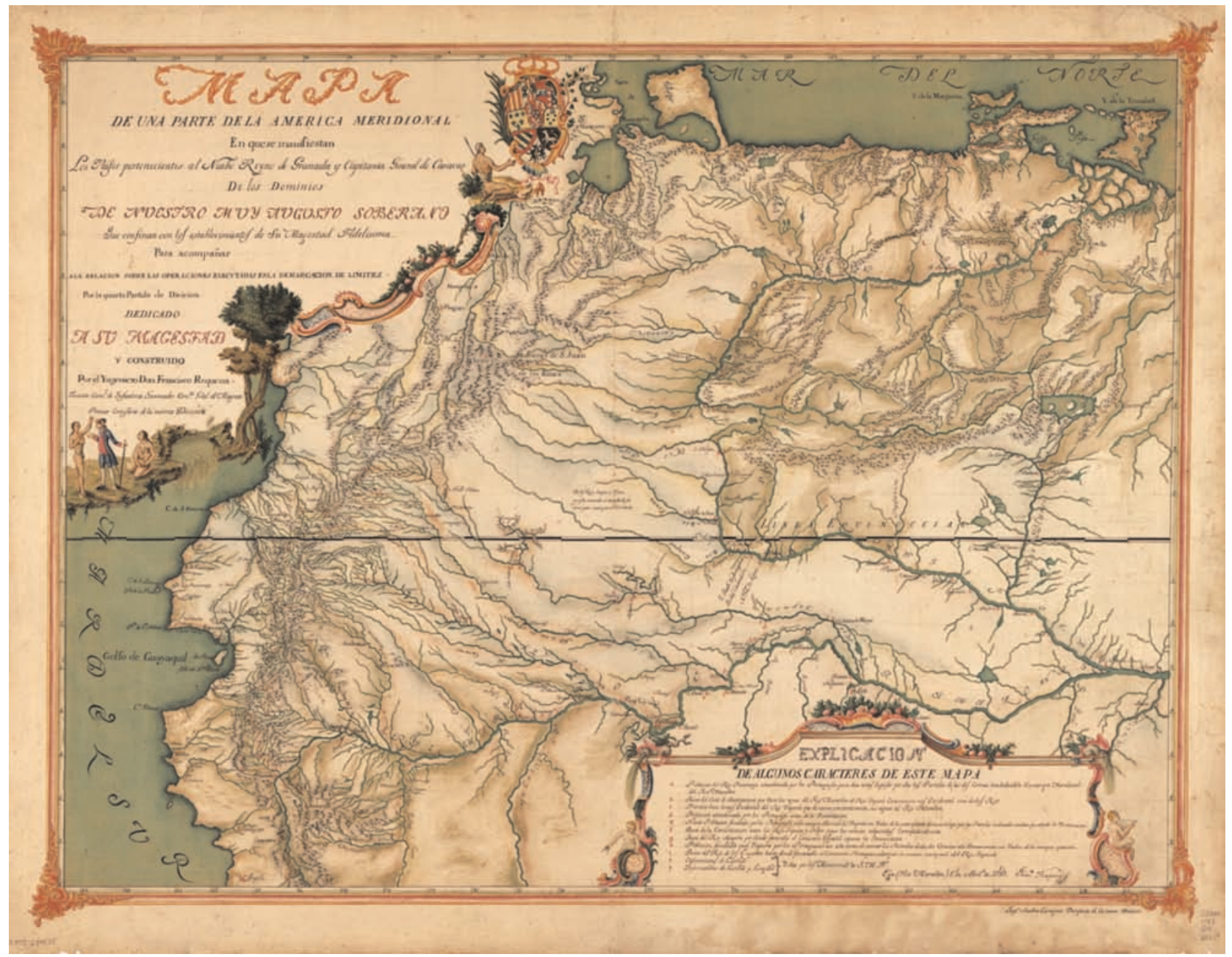

Figure 5. Mapa de una parte de la América Meridional [Map of one part of Meridional America]. Francisco de Requena. 1783. Library of Congress, Washington. Catalog Number 2003684535. 
the emergence of the expeditionary movement, we can understand why they were obsessed with visually capturing the new natural world they were discovering. Just the example of two botanists, who were connected to the Royal Botanic Garden of Madrid, is enough; Miguel Barnades, considered the person responsible for introducing the Linnaean System to Spain and Antonio Palau, the translator of Linnaeus.

'The principles of Botany' by Miguel Barnades (Printed by Antonio Perez de Soto, 1767) already indicated on the cover that it would be accompanied by "necessary illustrations", which tells us of his interest in visual representations together with classical textual descriptions. On page 12 he talks about the history of Botany and begins to describe the time of the Restorers in the Sixteenth Century, saying:

"... it is essential to cast again, let us say like this, Botany; studying plants, not in the books of the ancients, as the Commentators of the Greek works had done, but in the field of nature, observing them carefully, describing them, and drawing them faithfully..."

Talking of important Spanish botanists of that time, he notes Francisco Mico who discovered numerous plants in Catalonia, New Castile and Guadalupe and sent descriptions and many drawings to Dalecampio who put them in his General History published in Lyon in 1587. Monardes, Acosta, Ximénez, Hernandez, Lopez de Gomara and Fragoso are also highlighted, some of whom had discovered new species and often had depicted them, such as Gonzalo Fernández de Oviedo (Álvarez, 1993).

Passing to the time of the taxonomists of Botany, notably to Tournefort, he says (p. 16):

\footnotetext{
"This establishment of method in the herbal study, the most advantageous to Botany since its early days, was accompanied by several discoveries of new plants, which they did from those cultivated from Morison; and the invention of prints taken from these same plants in their natural state, recorded in copper, and some illuminated and decorated with bright colours."
}

Yaiza García has reminded us that already in the Nineteenth Century the term "print" existed to designate the final result of the printing of images on silk, paper or parchment, using a metal matrix. He gives an example of the use of this technique, of the Seville doctor Nicolas Monardes, who in 1574 published the first edition of his 'Historia medicinal de las cosas que se traen de nuestras Indias occidentales' (Medical History of the things that were brought from our West Indies'), with quality illustrations. It would be from the Eighteenth Century onwards, when techniques such as engraving points, recorded in black or smoke and aquatint would be added to traditional techniques like woodcut, Burin and etching until finally, they arrived at colour woodcuts (García Sánchez, 2011: 76-77) (figure 6).
Among those who encouraged the creation of prints, Barnades noted Breynio, Petiver, Plukenct, Merian, Pontedera, Dillenio, Micheli, Catesby and Miller. He also highlighted the ferns drawn by Plumier in America. After commenting on the important discoveries of the recent times at the far ends of the Earth, by the disciples of Linnaeus among others, he said (p. 23):

"The naturalness of the drawing, the delicacy of the engraving, and the vividness of the colours shine competence into many botanical works of this latest period..."

However, he criticized the lack of description and drawing of the old Botanists (p. 29):

"Nobody can ignore the fact that the ancients did not leave drawings of the medicinal plants they dealt with nor descriptions so that posterity might take advantage."

Barnades himself included 13 pictures at the end of his work (Dom. Gallicioli del., MT fc.) to show the difference in the roots and stems, to differentiate the leaves, kind of leaves, coverings, parts of fructification, differences in mantels and nectar, the flowers and

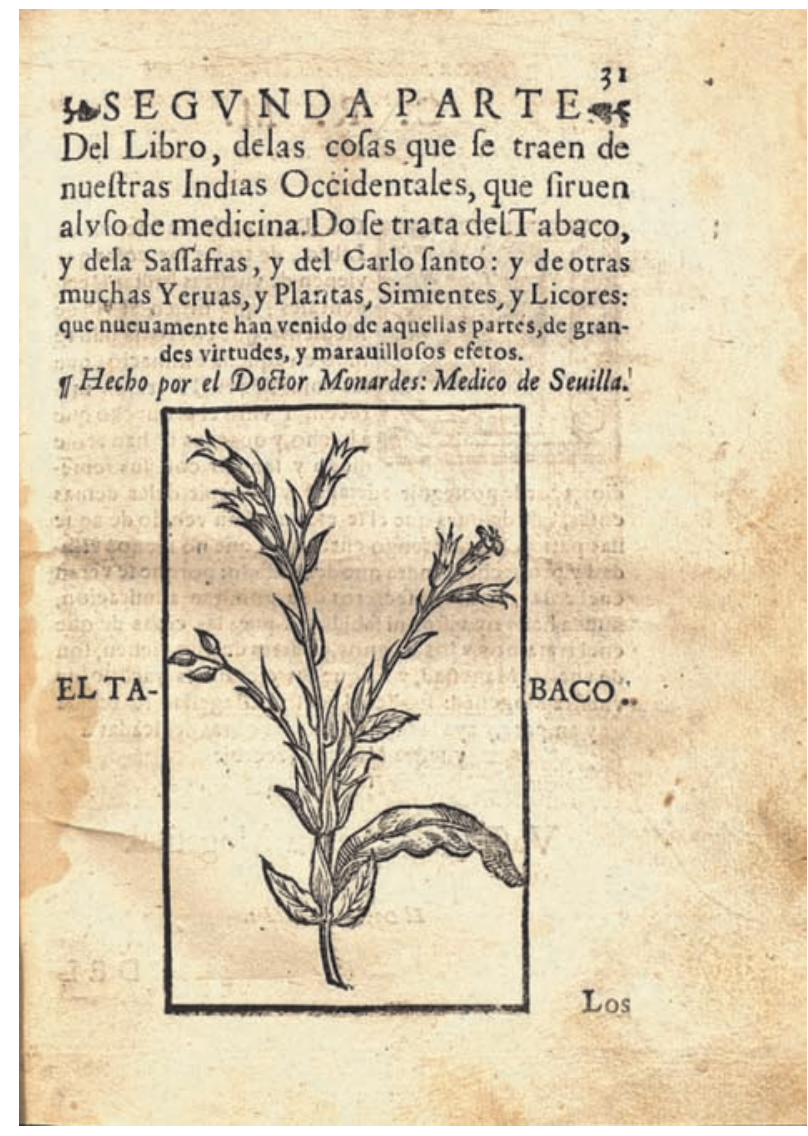

Figure 6. Tobacco. Nicolás Monardes. Segunda parte del libro de las cosas que se traen de nuestras Indias Occidentales. Sevilla, 1580 
their arrangements, differences with respect to the stamens, their sex, fruits and receptacles.

Antonio Palau in his 'Explicación de la filosofía y fundamentos botánicos de Linneo' (Explanation of the philosophy and botanical foundations of Linnaeus), Madrid, 1778, also includes 9 plates explained at the end of the work. On pages 238-239, in the chapter "From the library", classifying the different types of botany he speaks of the ICHNIOGRAPHI figures Vegetabilium iconibus expresserunt:

"The Ichniographos are those Authors who expressed the forms of the Vegetables with drawings. The Commentators were often mistaken in their inquiries of the species; and for this reason it was appropriate to paint and describe them, so that the names of those known were not confused with the unknown. Among the Authors from long ago, few forms are found to have perfection; and although in our century there has been great progress in the art of drawing, artists still commit many mistakes in the depiction of the smallest parts of plants. Many forms that the Ancients left mislead us, showing as straight the plants which by nature are creepers; and the same happens by expressing large trees, herbs and small plants with equal magnitude.

Forms are engraved in wood, copper and tin: those which appear in copper are more beautiful than those of tin; and those of wood are often rough and imperfect. Some Authors draw forms in outline or in profile, and these are lighter than the illuminated ones; because the colours usually fade and obscure the finer profiles of plants and flowers."

Afterwards he gave some examples of authors who engraved botanical forms such as Dillenio, Rivinio, Clusio, Plumier, Bauhinio, Lobel, Mathiolo, etc., but finally he insisted that a good Herbarium was better than all the forms for giving instruction, as Gómez Ortega would also do in the Elementary Course of Botany, another of the works that would often accompany the expedition members.

\section{THE EXPEDITION OF RUIZ AND PAVÓN TO PERU AND CHILE}

The first strictly botanical expedition sent by the King to the Peru and Chile in 1777 was explained by its leader, Hipólito Ruiz, in this way:

\footnotetext{
"Our Majesty the Catholic Monarch don Carlos the third wishes that his vassals achieve all the profits and benefits, by way of methodical knowledge, that can be taken from the vegetable kingdom, also that Botany is brought to all his American Domains and that in this way they go discovering and propagating medicinal plants and other interesting things for trade, manufacturing, the arts and other economic uses. He commanded the Royal Warrants to be issued on the 8th of April 1777 so that the two botanical disciples of his Royal Garden of Madrid can travel to these mention kingdoms with two artists to
}

observe, describe, draw and create Herbariums of the vegetables discovered in those parts of South America" (Ruiz, 2007: 97)

Two artists from the Royal Academy of Fine Art of San Fernando were chosen for the expedition: Joseph Brunete (1746-1787) (in some documents he is known as Brunet), a disciple of Rafael Mengs, and Isidro Gálvez (1754-1829), who were accompanied by botanists Hipólito Ruiz, José Pavón and J. Dombey. When this last member returned back to Europe the team grew with the appearance of Juan José Tafalla and the painter Francisco Pulgar on the scene, who later would be replaced by the Peruvian painter José Gabriel Rivera, and later, in 1800, we find the Quitan painter Xavier Cortés, who had already been an artist in Mutis company to New Granada (figure 7).

\section{THE INSTRUCTIONS TO THE ARTISTS}

Once Brunete and Gálvez were appointed, he proceeded to issue an 'Instruction that must be observed by the artists who travelled to Peru by the order of S.M. to serve by exercising their profession in the Botany Expedition'. This consisted of five priority

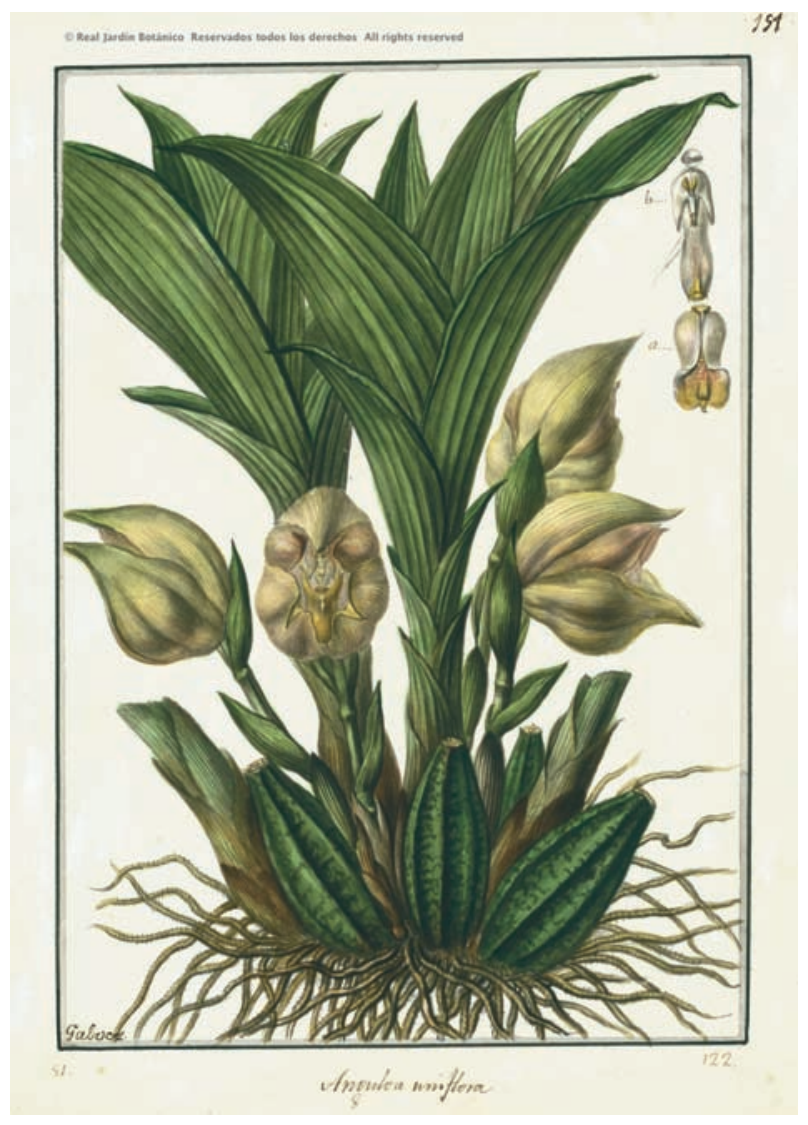

Figure 7. Angulosa uniflora. Isidro Gálvez. Botanic Expedition to the Viceroyalty of Peru (1777-1788). Archivo del Real Jardín Botánico (CSIC), Madrid. Div. IV, 1271. Reproduced with permission. 
points so the artists "should keep to strictly copying nature in their productions", without attempting to elaborate it or add elements of their imagination. They should strictly follow the orders of the botanists detailing, when important, whichever part of the plant even by increasing its size. Likewise they were ordered to draw parts of the flower and the fruit together with the form of the plant, "drawing their anatomy", endeavouring to do the drawings when the plants were still fresh, something insisted upon by other instructions to the Botanists. Also it was expected that the botanists give a size model for the plates so as to make them uniform and an adequate size for later publications, thereby avoiding the cost of reduction. In reference to colour it was indicated that they were satisfied with illuminating those rare or beautiful plants which deserved it, and in this case it was recommended to depict a flower, a fruit, and some parts, leaving the rest in ink, in this case to be coloured on the return to Spain. This was also the case for any special bird or others deigned worthy to be described and drawn. Finally it was indicated that the botanists would be helped with the formation of herbariums and manuscripts, etc. (Barreiro, 1931: 375) (figure 8).

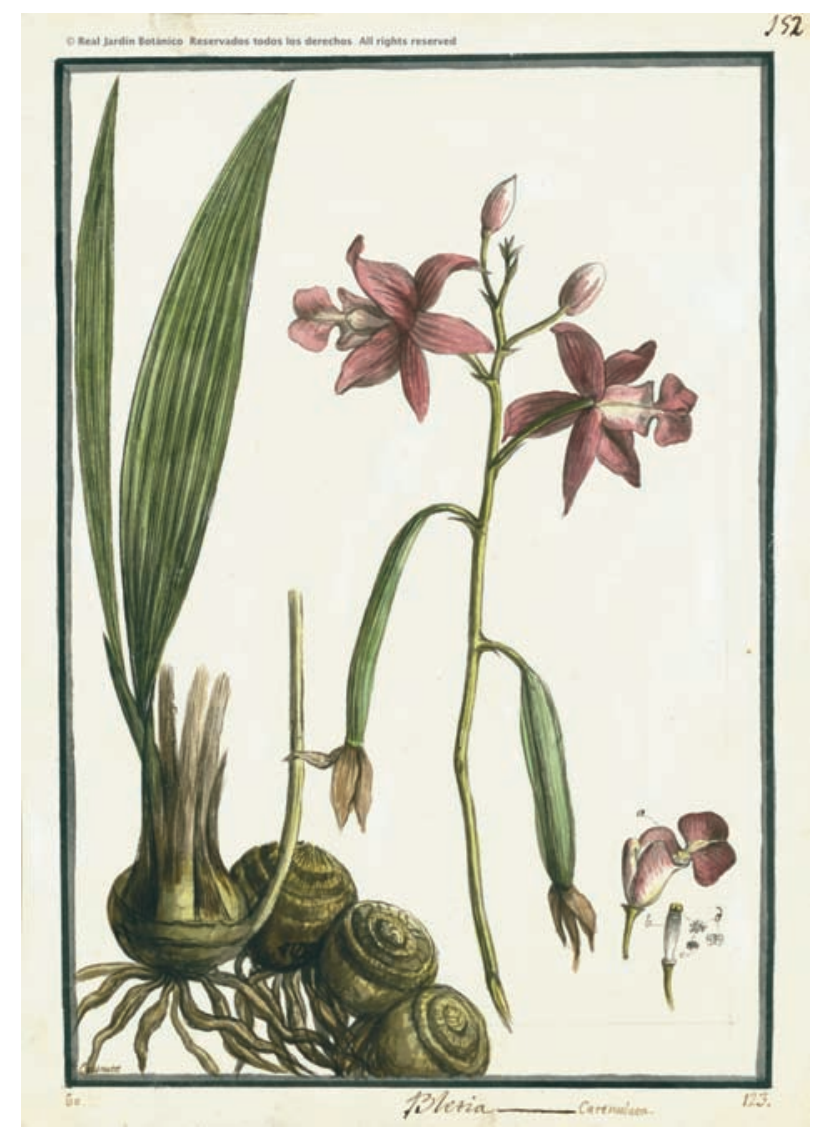

Figure 8. Bletia catenulata. José Brunete. Botanic Expedition to the Viceroyalty of Peru (1777-1788). Archivo del Real Jardín Botánico (CSIC), Madrid. Div. IV, 1274. Reproduced with permission.
These instructions were in fact quite similar to others circulating in Europe, since they all also responded to the same scientific paradigm, although in general the Spanish scientific expeditions were more influenced by the French model (Pelayo, 2003). Outside this we can see for example the Portuguese case. In 1779, in Portugal the Italian naturalist Domenico Vandelli wrote a memoir entitled 'Viagens Filosóficas, ou Dissertaçao sobre as importantes regras que o filósofo naturalista, nas suas peregrinaçoes, debe principalmente observar' in order to study the natural wealth and to plan an effective colonial policy. In the instructions for Alexandre Rodrigues Ferreira's expedition of 1783, which took two naturalist artists - José Joaquim Freire and Joaquim José Codina - objectives were set which were similar to the Spanish ones and some authors such as Costa and Diener indicated that the activity of the artists was absolutely secondary and subordinate to the objectives of the expedition, without which artistic subjectivity could not be performed, in the Portuguese case it was relatively easy to subordinate the artists or tracers in the military world, which was alien to the tradition of the artistic academies (Costa and Diener, 2000).

\section{THE WORKING CONDITIONS OF THE ARTISTS IN PERU}

For understanding the artists' working conditions there is the valuable testimony of Hipólito Ruiz, who complained about their indifference after the fire at the Macora ranch when the botanists lost much of their work, as well as their reference books (the works of Linnaeus, Murray, Plumier, Jacquin, etc.), paper, presses and their personal belongings, they had left the expedition headquarters without permission, in a sort of rebellion motivated by the harsh conditions of life, despite the fact that they had made a pact with the botanists to be on this trip for three months:

\footnotetext{
"Our artists, as always, work with all the possible comforts without leaving to go to the field or forest and without the hikes the botanists do almost daily on foot, free from these two little annoying diseases, as well as from the continuous fatigues, knocks, falls, heat, hunger, thirst, downpours, storms and damage to clothes that because of those harsh and rough mountains and mountain ranges we botanists endure." (Ruiz, 2007: 264.)
}

Ruiz also complained of the illustrators' lack of care on some occasions, as on this Macora Excursion, when they only made between two and four incomplete drawings a day. They also sometimes refused to draw the fructification parts first before drawing the whole plant, before it had withered, meaning that some plates did not contain these parts. They had also refused to repeat the 800 plates which had allegedly been lost in the wreck of the ship San Pedro de 
Alcantara off the coast of Portugal. Despite the botanical leader's negative comments, after the death in May 1787 of the artist Brunete, Ruiz - who the artist had named executor in his will - praised the conduct of his painter on these excursions near Pasco, who no doubt had lost his life by being over-zealous in his mission. (Ruiz, 2007: 291-292)

\section{THE AMERICAN FLORA OFFICE}

After the Ruiz and Pavón expedition returned to Spain, an Office was created to change the place of where the accumulating natural history materials should be studied and the publications of the 'Flora Peruviana et Chilensis' prepared (Rodríguez Nozal, 2001). In 1789, the expedition members had already set out a plan for carrying out the work of classification, organization, and orders for engravers and illustrators. (Rodríguez Nozal, 1995).

In addition to the problems that Hipólito Ruiz had with the artist Gálvez and partly with Pavón during the expedition, there appeared new ones in the heart of the new Botany Office, this time also with Casimiro Gómez Ortega, the almighty mandarin of Spanish Botany, who showed his misgivings about Pavón and Galvez accusing them of too little activity and too much ambition. The problem was further aggravated in 1793 by the recruitment of the artist José Rubio, a former student of the Royal Academy of Fine Arts of San Fernando, to support the work of Flora Peruviana. In the third year and there had already been complaints from the rest of the team to Jovellanos - then Minister of Grace and Justice - at the slow pace and inadequacies of this painter's work, aggravated by Rubio's supposed illness, in 1799 he was finally assigned to the Royal Porcelain Factory.

Despite the problems, this expedition was one of the few to offer scientific results, while at the same time, having a good sample of pictorial work by the naturalist artists. In 1794, the first novelties of the 'Flora peruvianae, et chilensis Prodromus' were published in Madrid, then shortly afterwards the 'Systema Vegetabilium' (Madrid, 1798), and the first three volumes of the 'Flora Peruviana et Chilensis' (Madrid, 1798-1802) (González Bueno and Rodríguez Nozal, 1996). The work of the artists was extraordinary considering that 2254 plates, 2230 botanical and 24 zoological survived with the signatures of Brunete, Gálvez, Pulgar, Rivera, Cortés and Carmona, the last survivor of the Löfling Expedition. The general style was guided by the Linnaean botanists; plant habitats, floral layouts, anatomies of fruits and seeds, with colours defined in ink and watercolours, the framed drawings with the Linnaean name outside the frame, and as such they followed the instructions with no concessions to imagination or the "landscape", although some plates were found; such as Brunete's one dedicated to Cecropia aspera where he drew a house with a human figure together with the habitat of the plant, but these would be the exceptions. Zoological drawings, however, followed general, even simpler patterns than the botanical ones, albeit with some simple detail of the habitat.

On the important printing work that was developed, Rodriguez Nozal and González Bueno have calculated a number of 536 engravings of vegetable genre and species, involving 51 engravers. (Rodríguez Nozal and González Bueno, 1995). There was an attempt to revive this editorial project with the return of Ferdinand VII in 1814, but it did not achieve its objectives because of organizational and economic problems that finally led to all materials being deposited in the Royal Botanic Garden of Madrid in 1831 (figure 9).

\section{A BOTANICAL DRAWING SCHOOL IN THE HEART OF NEW GRANADA}

The second botanical expedition that Charles III organized was that of the Cádiz doctor José Celestino Mutis to the Viceroyalty of New Granada. Although actually the Monarch, the only thing he did was to officially sanction a decision made by ArchBishopViceroy Caballero Góngora in 1783, after Mutis made

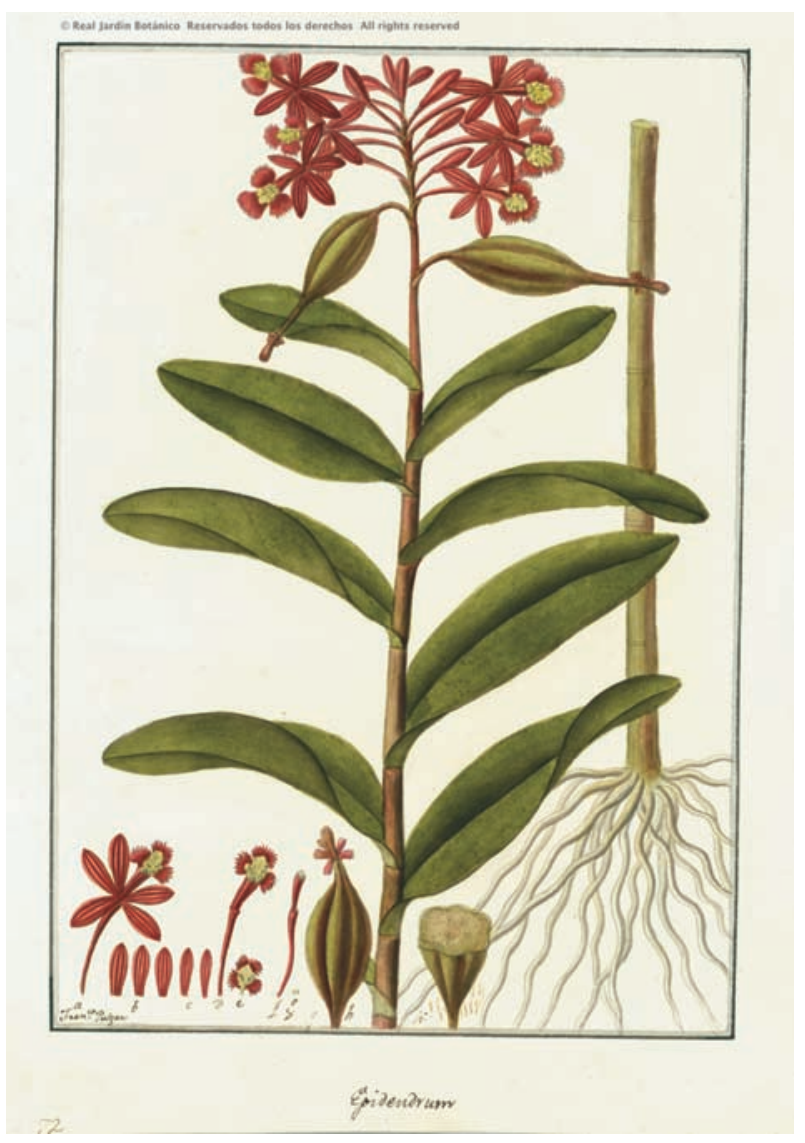

FIgURE 9. Epidendrum corymbosum. Francisco Pulgar. Botanic Expedition to the Viceroyalty of Peru (1777-1788). Archivo del Real Jardín Botánico (CSIC), Madrid. Div. IV, 1280. Reproduced with permission. 
several requests to the Spanish Court (Hernández Alba, 1983; Pérez Arbeláez, 1983; Amaya, 1986; Blanco and del Valle, 2009; Frías, 1994;Amaya and Puig-Samper, 2008 y 2009). Mutis had come to New Granada, in 1760, as a physician of the new Viceroy, Pedro Mexia de la Cerda, but with the clear idea of continuing his study of American nature, a job which he considered a continuation of Löfling's work. In the first depictions he made for the King in 1763 and 1764 , in order to get him to authorize the expedition, we can observe some of the objective interests that came up in Metropolitan science in other countries, such as knowledge of natural treasures and the formation of studios and botanical gardens (Peset and Puig-Samper, 1988). The political circumstances in Spain were not conducive to the expedition's creation, so it had to wait a few more years. Meanwhile, Mutis performed his medical jobs and contributed to forming the necessary educational foundations to create an enlightened elite in New Granada. Among his activities in those years it is important to note his work as Professor of mathematics at the Rosario College since 1762, his explorations in search of the controversial New Granadian quinine, his botanical shipments of drawings by the Bogota painter Pablo Antonio García del Campo to the great sage Linnaeus, and his attention to the mining of New Granada; he spent four years (1766-1770) in the La Montuosa mines, in Pamplona, and much later, between 1777 and 1781, in voluntary exile to those of Sapo, near Ibagué.

In his biography of Mutis in Michaud's encyclopaedic work, Alexander von Humboldt, when talking about Mutis' first phase of working as a doctor and his mining experiences, said:

\begin{abstract}
"The little money that our travel gained by practising his art, sometimes in the operation of the mines, he used to create a botanical library, to obtain barometres, geodetic instruments and telescopes to observe Jupiter's satellite constellations. He was associated with artists who drew very strange plants, and who painted the native animals in oil at normal scale. The author of this article has seen a part of this valuable collection, formed before Mutis became the object of the generosity of his sovereign." (Biographie Universelle ancienne et moderne, 1843).
\end{abstract}

Once the jobs were organized after the ArchbishopViceroy's approval of the 1782 expedition, Mutis' responsibility was overwhelming. He had to prepare a 'Flora of Bogotá' (Flora de Bogotá), organize the sealing of the quinine, acclimatize the cinnamon, bring his tea from Bogota, look for sources of mercury, test smelting or amalgamation techniques for mining, take preventive medical care precautions, etc. Nevertheless, once the headquarters were established in Mariquita, the expedition created a genuine scientific institution with centralized tasks, dedicated to various disciplines where the training of Creole scientists made the activities professional. It achieved some autonomy from Madrid to create a small scientific community with national characteristics. In the early days, Valenzuela was Mutis' main assistant, D Elhuyar was in charge of mining themes and Friar Diego Garcia and Antonio de la Torre initiated various explorations.

Furthermore, from 1784, Salvador Rizo ran a magnificent painting workshop dedicated to the Flora of Bogotá's iconographic representations, this relied on the participation of many artists, among whom included Francisco Javier Matis, the Cortés brothers, Vicente Sánchez, Antonio Barrionuevo, Antonio Silva, etc... In the Botany expedition Salvador performed the following responsibilities: artist painter and teacher of the Office of Painters, Butler (17841812); Director of the School of Drawing in Mariquita (1787-1791) and Santa Fe (1791-1812), and the Free School of Drawing in Santa Fe. He earned the title of "First painter" of the expedition by painting 141 plates. In the opinion of Mutis, his talent "for drawing and colouring was superior to that of his colleagues" (González and Amaya, 1996) (figure 10).

One of the best fruits of the expedition was precisely the work of these men, as Mutis' obsession

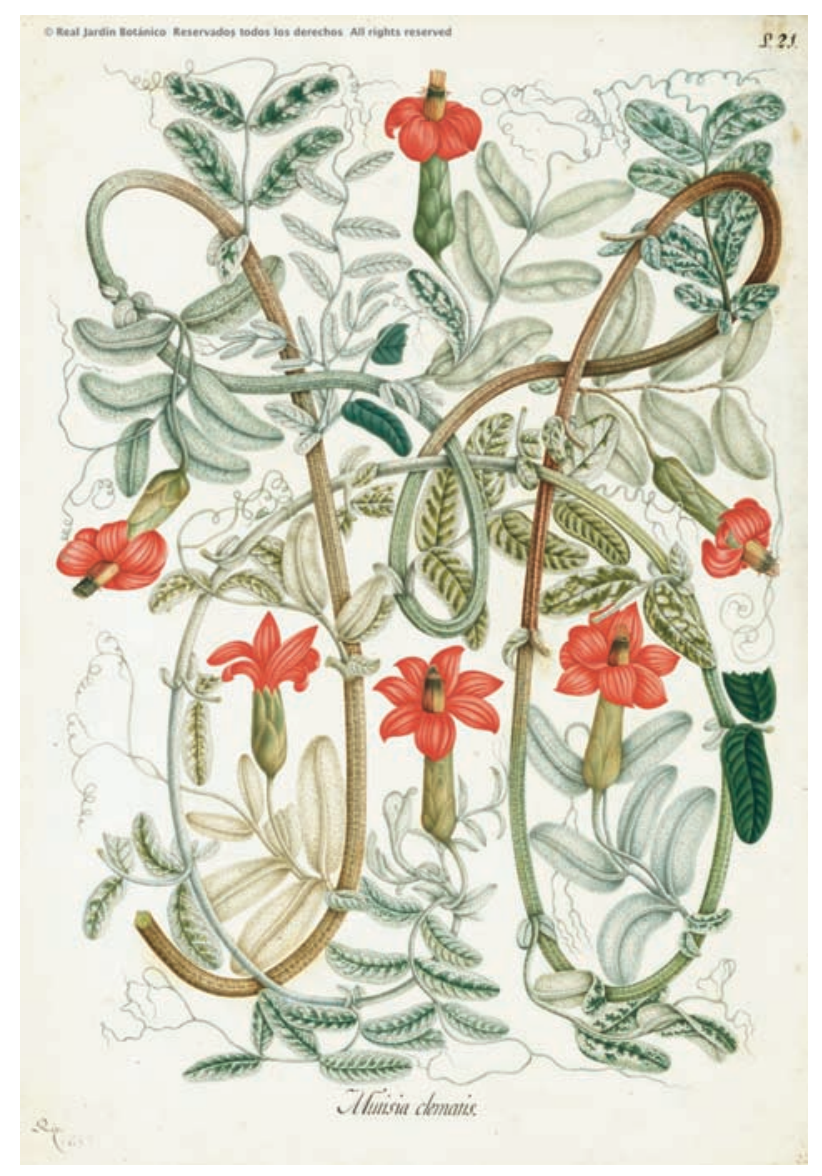

Figure 10. Mutisia clematis. Salvador Rizo. Royal Botanic Expedition to the New Kingdom of Granada (1783-1816). Archivo del Real Jardín Botánico (CSIC), Madrid. Div. III, 1154. Reproduced with permission. 
with faithfully depicting the described plants and using a peculiar colour technique - they used vegetable-extract dyes - resulted in a magnificent collection of 6,000 plates (Uribe, 1953). Regarding how these wonderful plates were done, sometimes they were only part-coloured, or anatomies or outlined the form of the plants while only emphasising some part, we have the testimony of Mutis himself to understand something:

\footnotetext{
"As the herbalists Roque and Esteban arrived with many uncommon plants, I put the best specimens in water for the subsequent formation of the plates, and doing what was usual on such occasions: for instance, outlining the entire plant, doing the fruiting anatomy and painting two leaves one to the right and one on the back. Although, for some, to save time this last part was left out conserving them in water" (Nieto Olarte, 2000: 87)
}

Daniela Bleichmar rightly pointed out that for Mutis the images were an integral part of the project to explore the American nature and formed a part of European science's globalization project, which was to create and circulate abstractions about nature that were visually-favoured (Bleichmar, 2006). As she notes "the images they kept were unstable and were transported far. More than mere illustrations or depictions, these images embodied objects and observation processes, giving European naturalists visual repertoires that allowed them to collect and compare natural specimens from around the world within the enclosed spaces of their studios" (Bleichmar, 2008). Cavanilles was therefore able to describe and study many plants arriving from the expeditions without moving from his studio, in a research separated from its place of origin and the time when the plant was found. In contrary to the botanists' declarations of principle, the plates reflected "types" which did not exist in nature showing also the flowers, fruits, roots, leaves both sheaf and underside, in a portrait that did not respect the natural seasons nor the accurate collection sites, but they made it possible to have a pattern for a genre or a particular species, something in which the artist was the main character, always relying on the invaluable presence of the herbarium's material. The dried plant was less showy, had largely lost its colour, but was the real material which later botanists could compare their specimens with. It was the necessary contract for the idealized type of naturalistic icon. In any case, as Nieto Olarte pointed out (Nieto Olarte, 2000: 69), the graphic representation allowed the complex natural world to be simplified, taming and made intelligible in the study process that was later done in the European studios, as this author states, the jungle, the tropics and the New World were places abundant with animals, plants and other natural history produce, but not the knowledge which was produced and approved in the laboratories, museums, botanical gardens and European studios, and then publicised by means of the printing press.

Among the painters who were Mutis' followers (Mutisans) Francisco Javier Matis stands out in the historiography, he painted many of the anatomies and moss drawings, doing 248 sheets, Humboldt and Bonpland dedicated the genre Matisia to him. Also noticeable was Antonio Barrionuevo, a painter from Quito who made 33 plates for the Royal expedition, as well as a series of 40 paintings to illustrate 'la Fauna cundinamarquesa' by Jorge Tadeo Lozano, depicting more than 400 species of animals which, according to González and Amaya, the Museum of Natural Sciences in Madrid received in 1817 (figure 11).

In 1791, Mutis was ordered to return to Santa Fe, where he was to reorganize the expedition which he was allowed to recruit new painters and assistants for, among them were his nephew Sinforoso Mutis and Francisco Antonio Zea, who were soon arrested and expatriated for participating in the pro-independence conspiracy against the Spanish Crown. Two years later he started to publish, in the Papel Periódico de Santafé de Bogotá, his work the 'El arcano de la quina revelado a beneficio de la humanidad' ('The secret of quinine revealed for the benefit of humanity'), ${ }^{4}$ was one of the few that would see the light of day. After pointing out the expedition's approval was dependant on operations being based in Santa Fe de Bogotá, including the artists' activity in the school of painting, Humboldt said:

\footnotetext{
"He was unable to make excursions around the Capital; but he sent the painters associated with his expedition to warm and temperate regions in the environment of the Bogotá Plateau. After a few years, the Spanish artists, who he gave advice to in order to perfect their talents, set up a school for young native artists. The Indians, both mixed and natural races showed extraordinary disposition for copying the shape and colour of the plants. The drawings of the flora of Bogotá were made on the Napier grand-aigle; they chose the busiest branches of flowers. The analysis or the anatomy of the fruiting parts was added at the bottom of the drawing. Generally each plant was depicted on three or four large sheets, both in colour and in black. Colours were drawn in part from native colouring materials and unknown in Europe. Never has a collection of drawings been made so luxuriously, nor on such a large scale. Mutis had taken the most admired botanical works of his time as a model: those of Jacquin, the heir and the Abbot Cavanilles." (Biographie Universelle ancienne et moderne, 1843: 659) (figure 12).
}

On the same page Humboldt stresses that during his 1801 visit to Mutis in Santa Fe de Bogotá, accompanied by Bonpland, he was able to see two thousand finished drawings, among which 43 species of passion flower and 120 species of orchids stand out. He also commented that Mutis had made duplicates with the idea of sending a copy to Spain and keeping 


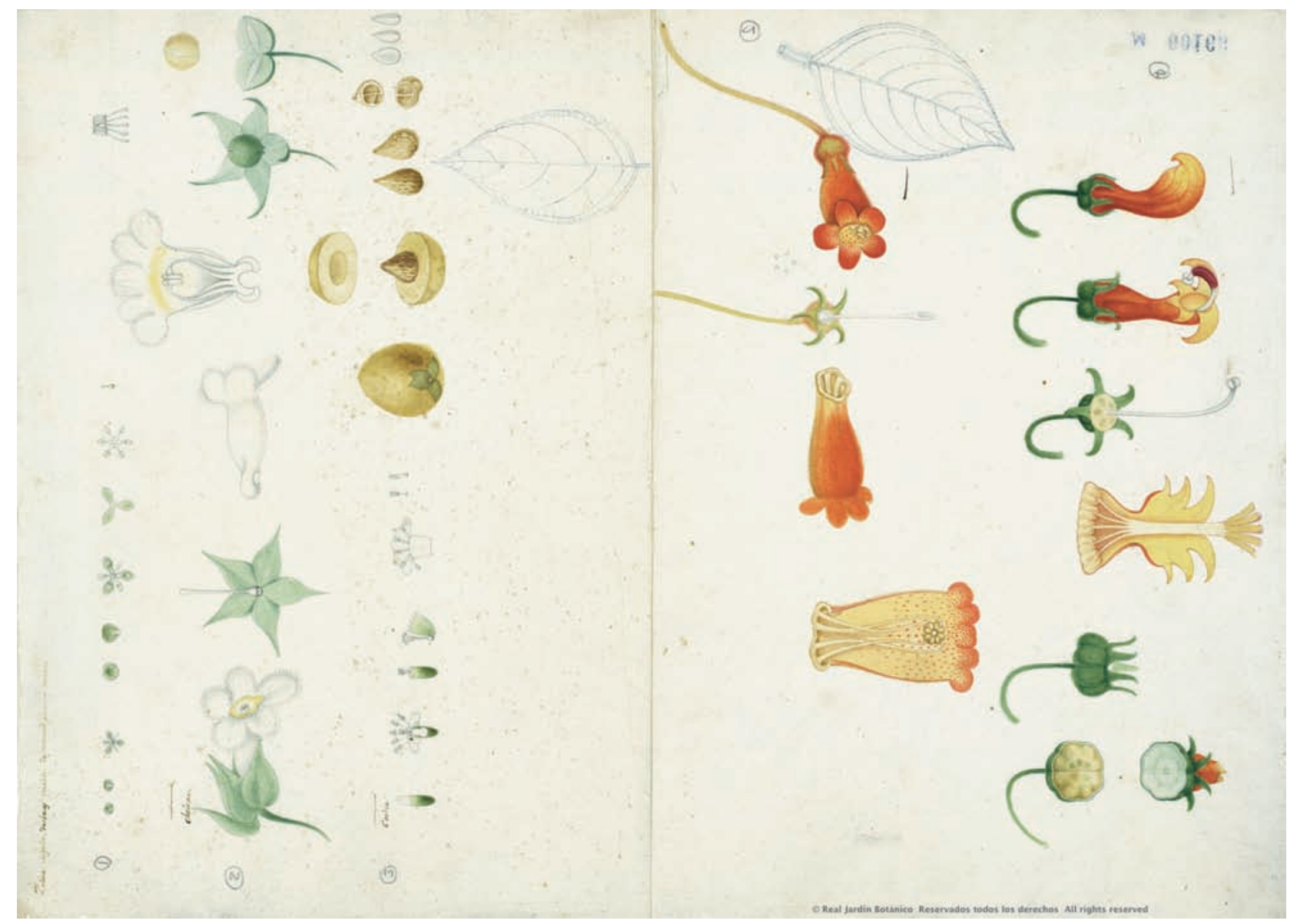

FIgURE 11. Flower dissection. Francisco Javier Matis. Royal Botanic Expedition to the New Kingdom of Granada (1783-1816). Archivo del Real Jardín Botánico (CSIC), Madrid. Div. III, M00166. Reproduced with permission.

the other in Santa Fe, while mulling over the idea of installing a printer at home and teaching the engraving trade to the same natives he had taught to paint.

He also mentioned the misfortune of Spain which because of its political situation had not been able to publicise the work of the Peru and Mexico expedition, and only part of Mutis's, although this was saved partly by his relationship with Linnaeus. Linnaeus had been famous in Europe for many years for his contributions to quinology and other discoveries such as "guaco" which was used as an antidote described by Humboldt and Bonpland as Mikania Guaco. With regards to the possible zoological drawings, Humboldt stressed that:

"He faithfully painted many species of mammals, birds and fish of New Granada" (Biographie Universelle ancienne et moderne, 1843: 661)

The last years of Mutis' life were also instrumental in forming the intellectual framework of New Granada. He achieved the creation of a Patriotic Society, almost at the beginning of the new Century, which Jorge Tadeo Lozano actively collaborated in - joining the expedition as a zoologist - and managed the medical school curriculum reform together with
Miguel de Isla, which was definitively linked to the advances of modern science. In addition, he retook old ideas about the formation of a botanical garden, the creation of a School of Mining, a chemistry studio, a Museum of Natural history and a University, while Francisco José de Caldas, the astronomer of the expedition and explorer of Ecuador, began the publication of the 'Semanario del Nuevo Reino de Granada' (The New Kingdom of Granada Weekly) (Saladino, 1990; Chenu, 1992; Nieto Olarte, 2007). After the death of José Celestino Mutis, in 1808, his main disciples directly participated in the independence revolts that were put down by the Spanish general Morillo, who shot most of the 'mutisians' in 1816, and ordered that all materials accumulated by the expedition, manuscripts, herbariums and engravings, be sent to the Peninsula to be examined under the wise eye of Metropolitan science (Peset, 1988).

\section{LAGASCA, TRUSTEE OF MUTIS' WORK IN MADRID AND HIS CLAIM AGAINST HUMBOLDT}

Mariano Lagasca, the disciple of Cavanilles, was entrusted to receive Mutis' legacy for his study 


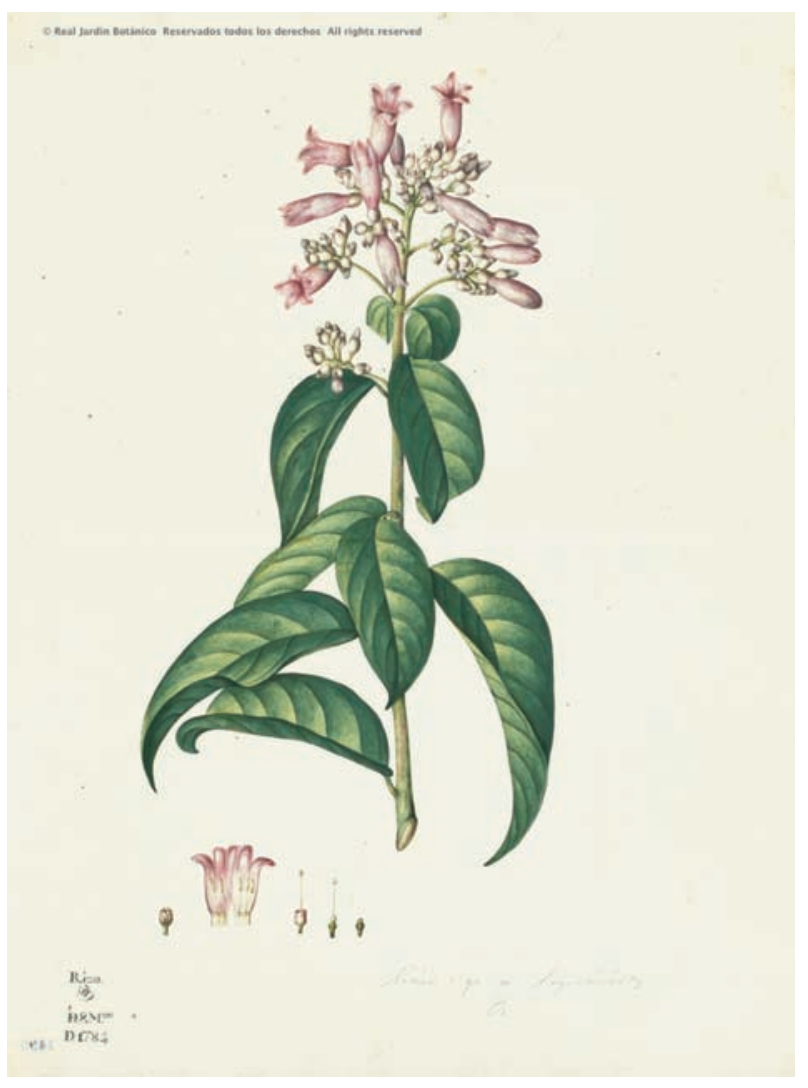

FIGURE 12. Maipa panamensis. Salvador Rizo. Royal Botanic Expedition to the New Kingdom of Granada (1783-1816). Archivo del Real Jardín Botánico (CSIC), Madrid. Div. III, 1495a. Reproduced with permission.

(Puig-Samper, Maldonado and Fraga, 2004). In a letter dated the 30th of April 1827 in London, when the botanist was exiled in the English capital, Humboldt wrote to him commenting on the state of the boxes that had arrived in Madrid:

\begin{abstract}
"All the boxes arrived in the best condition without having been damaged during the trip. Twelve of them came filled with drawings numbering a total of six thousand nine hundred sixty and nine, although the inventory only mentioned five thousand two hundred. Six thousand, more or less, of these drawings were done on exquisite quality folio paper; five hundred and ninety, on reduced paper, are copies of prints published in different works; and some three hundred on regular folio paper, solely depict the fructification of various genres. Of the first six thousand, half are in black and the other half is magnificently illuminated; for each plant there is a drawing in black and another illuminated, so the six thousand only represent about three thousand different plant species."
\end{abstract}

In another letter from Lagasca to Humboldt, dated the 3rd of May of the same year, he requested that Mutis be given credit as the intellectual author of the drawings represented in some of Humboldt's works such as 'Plantae aequinoctiales' as they had been copied from the José Celestino Mutis' 'Flora de Bogotá'. Lagasca insisted that if it were not done in Mutis biography being published by Humboldt, it would undoubtedly be published in the work of Michaud, he owed the wise Cadiz-native and his country this recognition as Mutis had so generously taken him with him on his American trip. Humboldt and Bonpland dedicated their work 'Plantae aequinoctiales', published in Paris in 1805, to José Celestino Mutis as leader of the Botanical Expedition to the Kingdom of the New Granada and Royal astronomer in Santa Fe de Bogotá «as a shy test of admiration and recognition». Even so, in the preface to his work, Humboldt was really insistent about the long length of his own botanical exploration compared to the expeditions of Mutis, Ruiz and Pavón or Sessé, Mociño and Cervantes. Regarding Mutis he commented:

\begin{abstract}
"Mr. Mutis reviewed, a long time before us, the Turbaco forests, the beautiful banks of the Madeleine and the vicinity of Mariquita; but this great botanist, whose kindness imposes on us an eternal recognition, could not penetrate the Quindiu Andes in the provinces of Popayán and Pasto. It is in these areas; on the edges of the Cauca and on the high plateau that extends from Almaguer until the city of Ibarra, that we have collected valuable plants" (Humboldt and Bonpland,1805: II)
\end{abstract}

Humboldt also clarified that he would add some interesting drawings to the descriptions of the new species, with details of the essential fructification parts - work of the illustrators Turpin and Poiteau, later recorded by Sellier -without making the slightest reference to those drawings copied from Mutis, whose authorship Lagasca had demanded in his letter. Yes, there appeared a comment expressing that Mutis drawings speak of quinines, in the description of 'Cinchona condaminea' where Mutis had discovered numerous species, "the Institute and the Museum own beautiful designs handed in by $\mathrm{Mr}$. de Humboldt on behalf of Mr. Mutis" (p. 37). Instead, he pointed out his priority in other cases like in the bejuco del guaco (Mikania guaco), discovered by Mutis, but depicted for the first time in 'Plantae aequinoctiales' (volume 2 , page 85 , plaque 105). The judgment of this dispute has been left for posterity, which still today has not been entirely clarified. From contact with Mutis, Humboldt could get important iconographic insights into American flora; useful for the descriptions of tropical flora, though sometimes difficult to be classified by the strict Linnaean system and, as Humboldt himself would later see, they fit better with the natural classification systems, which at that time his friend Jussieu was trying to develop, although it is clear that Humboldt's interest in painting from nature was going along other paths. Lagasca's argument was not the only controversy for Humboldt, 
since the relationship of the wise Berliner with another of Mutis' main contributors, Francisco José de Caldas, was not exempt from arguments about the priority of the altitudinal studies and its visual representation.

\section{CALDAS AND THE REPRESENTATION OF ECUADOR}

Francisco José de Caldas, as a member of the Mutis expedition, focused his iconographic contribution on two levels of representation. When it came to botanical iconography he was less demanding than his master. Caldas' dedication to Botany went back to 1801, a date when Mutis gave the 'Philosophia botanica de Linneo' (Linnaeus's Botanical Philosophy) and encouraged him to devote himself to studying Ecuador's flora, a task partially done one year before being officially appointed a member of the Royal Botanical expedition. In Caldas' watercolours called "Design of Plants", we find a collection of simple drawings, in colour or in black and white, often unfinished and with a Linnaean anatomical dissection, the result of their many excursions through the Ecuatorial territory between 1801 and 1805. Commenting on the possibility of making a 'Flora Quitoensis', Caldas goes on to say:
"The only way to retain the gathered information is by graphic reproduction. I do not claim that my work is drawn with as much magnificence as the Flora of Bogotá. Splendour is of little use and, if I may be permitted to use the expression, the literary luxury, if all they do is slow down the advancement of science. Small and simple plates of watercolour pages without miniatures and sketches only in black would suffice for my research." (Díaz Piedrahita, 1994). In addition to these drawings, Caldas took his master a collection of eptipas, impressions of live plants on the paper using a portable press like those usually used by botanists. Without a doubt they served as a guide for the Flora drawings, although they would always need additional colour information.

The other level of representation used by Caldas has to do with his 'Nivelación de plantas' (plant leveling) studies, similar in some respects to Alexander von Humboldt's 'Geografía de las plantas' (Plant Geography), which Caldas publicised in his 'Semanario' in 1809 translated by Jorge Tadeo Lozano, although more focused on the altitudinal study of specific genres such as 'Cinchona'; the famous and controversial New Granada quinine, or species with a medicinal and economic nature (figure 13).

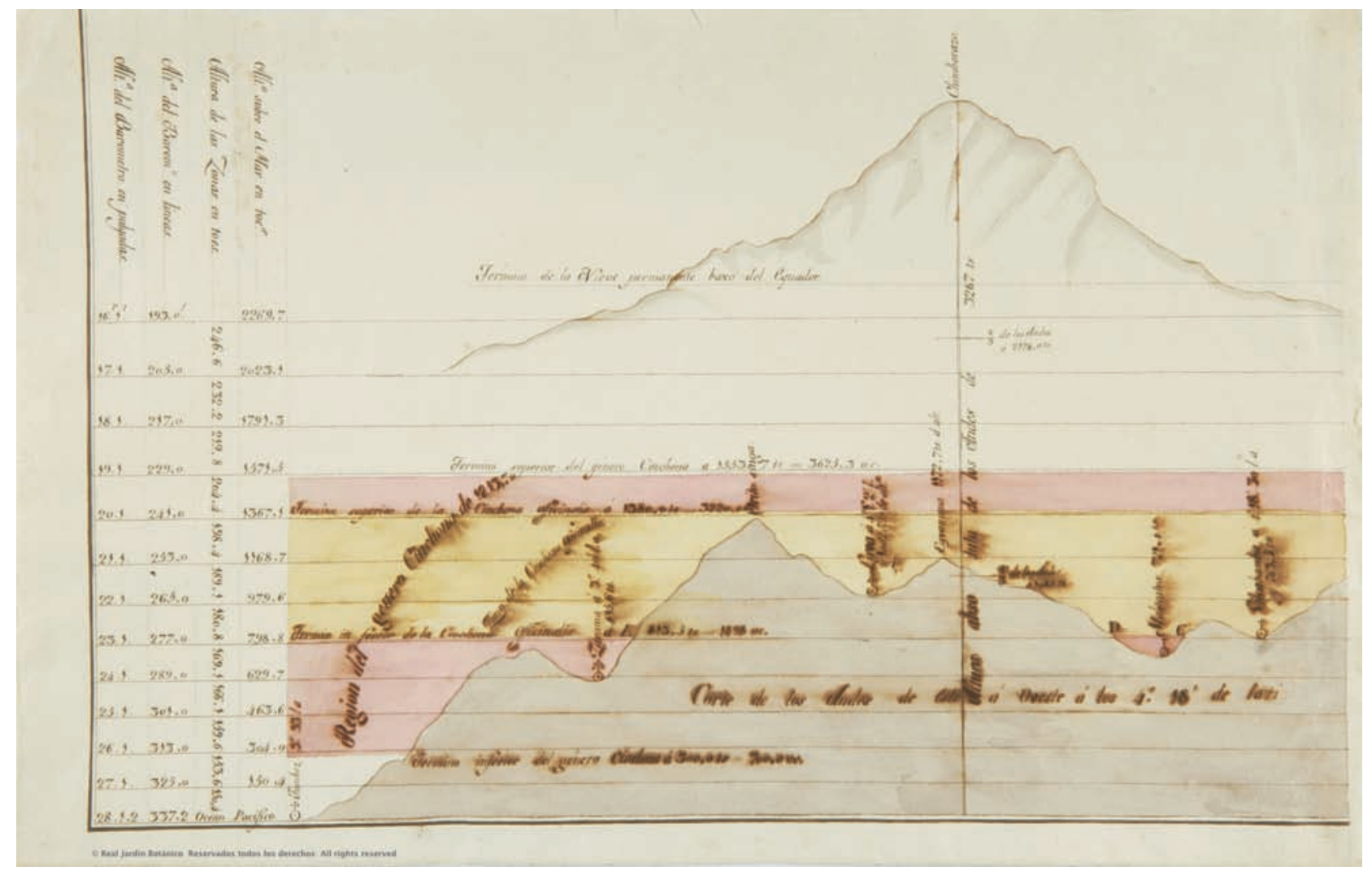

FiguRe 13. Altitude distribution of Quina shrubs. Francisco José de Caldas. Royal Botanic Expedition to the New Kingdom of Granada (1783-1816). Archivo del Real Jardín Botánico (CSIC), Madrid. Div. III, M00514. Reproduced with permission. 
Still discussing the independence of Caldas' work from Humboldt's in this type of work, something that at first seems to be true, but we also know that Caldas had the wise Prussian's first manuscript at his disposal. In a letter to José Celestino Mutis in April 1803 he commented that he had in his hands Humboldt's draft of the work:

\footnotetext{
"Mr. Baron von Humboldt, who left for Guayaquil for two months, put a tin cannon in the hands of Mr. Marques de Selva-Alegre, containing a report on 'Geografia de las Plantas'. I do not know why he kept it in his possession so long and he did not give me it for his referral by my hand, according to the wish of the Baron himself. I've held it up for 15 days to make a copy and I send it now accompanied by my own almost in the same genre, which I hope will be received. Yours, with kindness." 5
}

Caldas picked up maps and topographical charts related to this type of study, which are preserved in the Royal Botanic Gardens and accompany the 'Memoria sobre Nivelación de algunas plantas que cultivamos en las cercanias del Equador' (Report on the levelling of some plants that we grow around Ecuador) (signed in Quito on the 6th of April 1803) and also in the Army Geographic Service. In the most comprehensive series which is preserved in this second centre, studied a few years ago by Mauricio Nieto Olarte (Nieto Olarte, 2006), we can see an incredible map of Ecuador, composed of different pieces, with Equador's plants levels, in a representation that transcends mere botanical information to view the territory in a comprehensive manner, although in a different way to Humboldt's representation of nature used in his 'Cuadro físico de los Andes y países vecinos' (Physical picture of the Andes and neighbouring countries) which visualised his theory about plant geography (Puig-Samper, 2007).

\section{THE ROYAL BOTANICAL EXPEDITION TO NEW SPAIN}

The third botanical expedition to the Viceroyalties was destined for New Spain, in 1786, under the leadership of the Aragonese physician Martín de Sessé. The chance finding of Francisco Hernández's manuscripts, physician to Philip II, by the scholars Muñoz, Alzate and Bartolache, together with de Sessé's proposal from Mexico to make an inventory of New-Hispanic flora; in order to find their therapeutic uses and to reform the health professions, accelerated procedures for the approval of an expedition to the territories of New Spain (Arias Divito, 1968; Wilson Engstrand, 1981; Lozoya, 1984; Sánchez, Puig-Samper and de la Sota, 1987; San Pío and Puig-Samper, 2000). The Royal order was very explicit in marking the expedition's objectives, which included the botanical drawing of New-Hispanic natural produce:

\begin{abstract}
"Insofar as it is appropriate for my service, and for the sake of my vassals, that serve as an example of my Royal Order executed in the Kingdom of Peru, and Santa Fe, that they examine, draw and methodically describe the natural produce of my fertile domains in New Spain, not only with a general objective, but importantly promoting the progress of Physical Science; banishing the doubts and adulterations that are in Medicine, Dyeing, and other useful Arts, and increasing trade, but also especially with supplementing, illustrating and perfecting the affairs of the current state of Natural Science itself, the original writings that the physician to Felipe II left as fruit of the expedition of equal nature, financed by that monarch, and which so far has not produced the complete uses hoped for" (Maldonado and Puig-Samper, 2000).
\end{abstract}

To achieve this mission, Martin de Sessé was appointed director of the future garden and the expedition. Vicente Cervantes; Professor of Botany, Juan del Castillo; expedition botanist, José Longinos Martínez, expedition naturalist and Jaime Senseve: senior pharmaceutical Professor. The expedition's arrival to New Spain meant the introduction of modern natural history and Linnaean theories into this territories.

The first expeditionary activities took place in October 1787, in the outlying areas of Mexico City, where the techniques of botanical and zoological collection were tried out. Sessé, accompanied by the pharmacist Senseve, travelled different itineraries throughout the valley of Mexico, the forests and rivers of San Angel and the Carmelitas and los Remedios deserts. The following year the first general campaign began, which Longinos Martínez also participated in, whose operation centre was the town of San Angel, from where excursions to Yecapixtla and Xochitlán were made. Later, with the idea of reaching the Mexican capital in time for the end of the first botany course taught by Vicente Cervantes, they travelled around the outskirts of Toluca, where they found the "tree of hands". In the second phase of the expedition Castillo and two artists joined, Juan de Dios Vicente de la Cerda and Atanasio Echeverría Godoy, students of the Royal Academy of Fine Arts of San Carlos, New Spain.

The Royal Academy of San Carlos of the Noble Arts of New Spain was founded in 1781 by Charles III and Jeronimo Antonio Gil was appointed director (1732-1798) who had been Senior Recorder of the Casa de la Moneda (the Royal Mint), and had studied at the Academy of Noble Arts of San Fernando. This character, who recommended de la Cerda and Echeverría as expedition painters, was sent to Mexico by Charles III in order to establish a school of engraving to improve the minting of currency. Its foundation was inspired by the model of the Royal Academy of Fine 
Arts of San Fernando in Madrid and was the first Academy of art founded in the New World.

On the third campaign, launched on the 17th of May, 1790, the Mexicans José Mariano Mociño and José Maldonado; who had received their botanical training from Vicente Cervantes, were added to the expedition team - consisting of Sessé, Castillo and the painters de la Cerda and Echeverría. While this group was heading for Michoacán and Sonora, Senseve stayed in the Mexican capital to handle the expedition members' shipments and José Longinos Martínez organized the first Mexican Natural History Studio. While the bulk of the expedition explored the Mexican territory, he authorized an exploration journey with José Longinos Martínez in charge. He travelled to San Blas de Nayarit and the two Californias to study the natural produce (Bernabéu, 1994).

When the campaign ended the naturalists met in Aguascalientes, the Viceroy Revillagigedo ordered that Mociño, Maldonado and Echeverria join the Juan Francisco de la Bodega y Quadra's expedition to the Northwest of America (1792), which resulted in an abundant collection of natural produce and some interesting ethnological news that Mociño picked up in his 'Noticias de Nutra' (Nootka News) (Monge and Olmo, 1998).

The expedition was running out of time, so Sessé requested additional time to explore the so-called Guatemala line and the Windward Islands in two groups. The first group, composed of Sessé, Jaime Senseve and Atanasio Echeverría, sailed to the island of Cuba in May 1795, (Puig-Samper, 1991b). There they were joined by the Cuban doctor José Estévez, pensioned from the Royal Consulate and supported by the Havana Patriotic Society in order to train beside Martín Sessé as a botanist. The expedition of the Caribbean Islands could not perform all the objectives after the Puerto Rico exploration, as the riots of Santo Domingo and the Declaration of war against England forced them to return quickly to Havana, where they arrived on the 1st of June 1797. On the island they met with the arrival of another expedition from the Peninsula commanded by the Earl de Mopox y de Jaruco (Higueras, 1991). This expedition, carried out between 1796 and 1802, with primarily military and economic objectives (tracing the Guines canal, founding populations in strategic areas, etc...), was aided by the services of the Aragonese botanist Balthasar Manuel Boldo and naturalist artist José Guío (Sotos Serrano, 1984).

In the circumstances it was advisable for Sessé to wait so as to make his collections of the island accompanied by Estevez y Echeverría - who soon would become part of the Mopox expedition - along with the recent arrivals. The artistic work of this latest expedition resulted in a valuable collection of plates of plants and "insects" drawn by Guío and other birds and fish, now lost, painted by Echeverria.
The second group of the New Spain exhibition, made up of Mociño, Longinos Martínez, Vicente de la Cerda and the new assistant Julian del Villar, left Mexico in the direction of the Kingdom of Guatemala in June 1795 (Taracena Arriola, 1983; Maldonado Polo,1997; Maldonado Polo, 2001). José Longinos Martínez founded a Natural History Studio in 1796 in Guatemala and Mociño organized a Flora de Guatemala (Guatamalan Flora) with artwork by Vicente de la Cerda, published only a few years ago (Maldonado Polo, 1996). Finally, the expedition members reunited in Mexico between 1798 and 1799 , organized the shipment of historic-natural materials, before returning to Spain in 1803.

\section{THE RETURN TO SPAIN AND THE RESULTS OF THE NEW SPAIN EXPEDITION}

At the end of 1803, after sixteen years of Expedition in New Spain, Sessé and Mociño -already in Madrid- resumed their activities and began the recovery and organization of all materials that had been referred to the Royal Botanical Gardens during their explorations, as well as other materials which they had brought to the Peninsula, trying to gather all drawings, manuscripts and herbarium specimens in a single quota. These, properly studied and organized, would be used for the publication of la Flora Mexicana' (Mexican Flora), but the troubled Spanish political landscape since the beginning of the Nineteenth Century and the apathy and indifference of their rulers, meant that this scientific legacy would not be used at the time and suffered many problems, losses, sales, etc., without obtaining the scientific profits that Spanish science should have had.

Sessé and Mociño, as well as artist Echeverria, who also was in Spain, were devoted to the job of retrieving and organizing the materials that must be found in any of the departments assigned by the King. In the end, the work could not be finished, Sesse died four years later and Mociño was then put in charge of everything related to the expedition, organizing and classifying all the materials and trying to conclude a 'Prodromus' of the 'Flora of Mexico', but as it dealt with sorting out thousands of objects, he alone wasn't enough for this task, he saw the need to ask the King for the assistance of Atanasio Echeverría, who at that time was still in Spain. Much later, because of the problems suffered by the Mexican botanist, who was exiled to Montpellier and Geneva, the work could not be published, though the drawings were partially duplicated in the collection known as the "Geneva Ladies' and some species validly published by De Candolle, based solely on the icons, demonstrating the important role of the plates in the world of botany and natural history (Burdet, 2000; Flores, Godínez et al., 2010). Mociño, on his return from exile, tried again to value the New Hispanic scientific work, something that was frustrated by the botanist's death soon after 
returning to Barcelona, where some two thousand of the important collection of drawings by Echeverría and de la Cerda disappeared, which is currently kept in the Hunt Institute of Pittsburgh and has been studied by Roger McVaugh (White, McVaugh et al., 1998; McVaugh, 2000), a collection that contrasts with the small collection preserved in the Royal Botanical Garden in Madrid (Zamudio, 2000; Zamudio, 2010).

Regarding the technique used by Echeverría and de la Cerda on the expedition plates, Yaiza García notes that they were watercolours made with a refined and exquisite technique, which consisted of sketching the drawing in pencil with a thin, delicate and sure line. Then they did a grisaille on a base of china ink or bugallo applied by brush or pen and finally watercolour was applied on a base of superimposed colours until creating the desired volume, using two types of paper, the 'Catalunya' for sketches and ' $J$. Koolcoronado' by a Fleur de lis for the higher quality plates. They had to use metal spikes of lead to outline their drawings, or else the pencils that had begun to be manufactured in those days. And they were always framed thinking that the final process would end in an engraving (García Sánchez, 2011: 76-77) (figures 14 and 15).

The greatest scientific fruits of the Botanical Expedition to New Spain were manifest in the compilation of thousands of descriptions and botanical data of New Spain's flora, which finally managed to appear as the two posthumous works of Sessé and Mociño: 'Plantae Novae Hispaniae y Flora Mexicana.' (Plants of New Spain and the Mexican Flora') was published in installments, the first between 1887 and 1891 and the second from the latter date until 1897, as an appendix to La Naturaleza (Nature) journal of the Mexican Society of Natural History. In addition, 'la Flora de Guatemala' (The Flora of Guatemala) was published later, and 'la Ornitología de Nueva España (The Ornithology of New Spain)'; which has only been recently discovered (Puig-Samper and Zamudio, 1998; Maldonado and Puig-Samper, 2006), and is still unpublished, currently under study and is probably the most relevant zoological contribution of the expedition (NavarroSigüenza et al., 2007) (figures 16, 17 and 18).

\section{THE PAINTERS OF THE MALASPINA EXHIBITION}

The enlightened policy designed by Charles III, Charles IV and his ministers to understand, reform and ensure the Spanish Empire's American possessions by sending scientific expeditions, reached its moment of greatest splendour with the organization of Alejandro Malaspina's expedition around the world (17891794), the Italian navigator who was in the service of the Spanish Navy and who, with José Bustamante, prepared this company (Sáiz, 1992; Higueras, 19871999; Palau, 1984; Lucena Giraldo and Pimentel

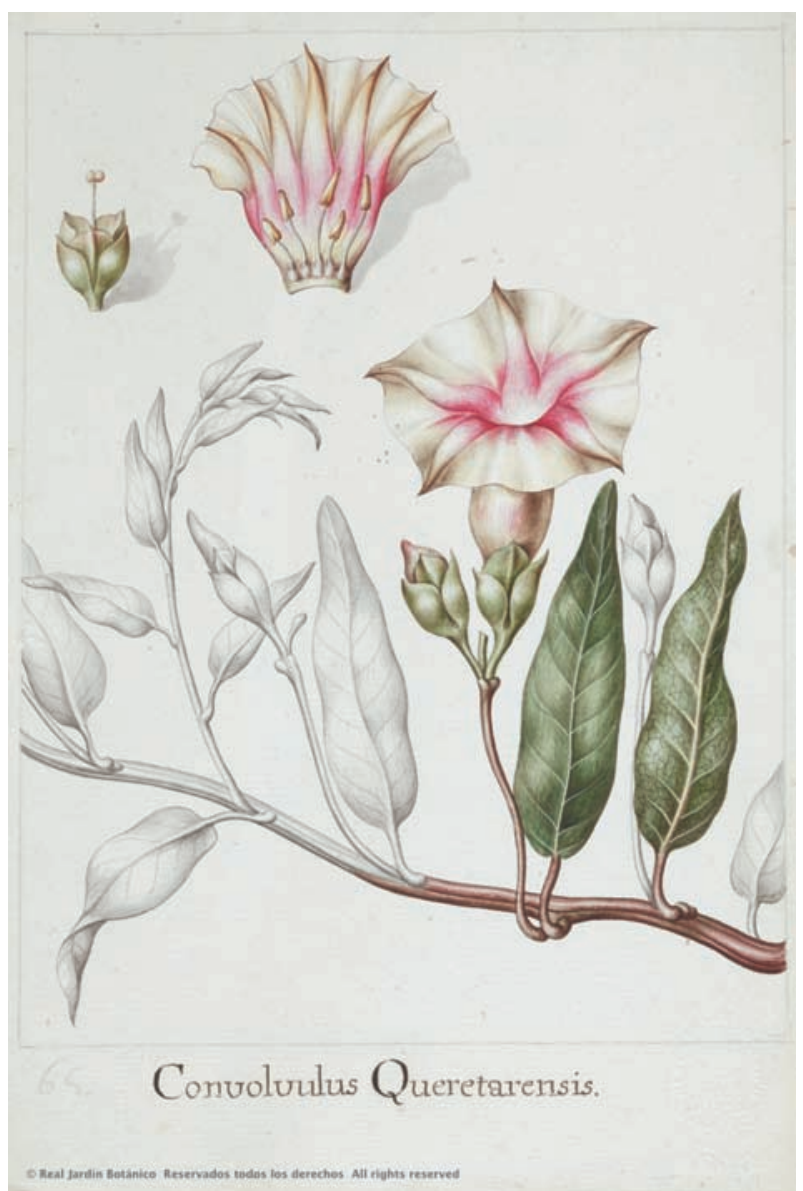

Figure 14. Convolvulus Queretarensis. Royal Botanic Expedition to New Spain (1787-1803). Archivo del Real Jardín Botánico (CSIC), Madrid. Div. V, 47. Reproduced with permission.

1991; Manfredi, 1994; Pimentel, 1998; Sagredo Baeza and González Leiva, 2004).

The artistic works of the Malaspina expedition were carried out by a group of artists and painters, who were continuously changed throughout the expedition. Their work is reflected in an important collection of over 800 drawings, in which we can observe everything from the appearance and customs of the peoples they visited to the detailed analysis of the animals and plants collected or seen during the trip (Palau, 1980; Sotos Serrano, 1982). The first we speak about is the Seville-native Jose de Pozo Ximénez, hired as an expedition painter in June 1789. He had been a student at the Academy of Seville and at the time of his recruitment was described as "an excellent subject and perspective painter, having a very good education, with a wealth of geometry and is very robust for the age of 32". He was one of a group of artists that left Cadiz with the official expedition and was one of the perspective and portrait specialists, although he also had a high output of water-colour drawings of plants and animals. The ethnological portraits are probably his greatest contribution to the 


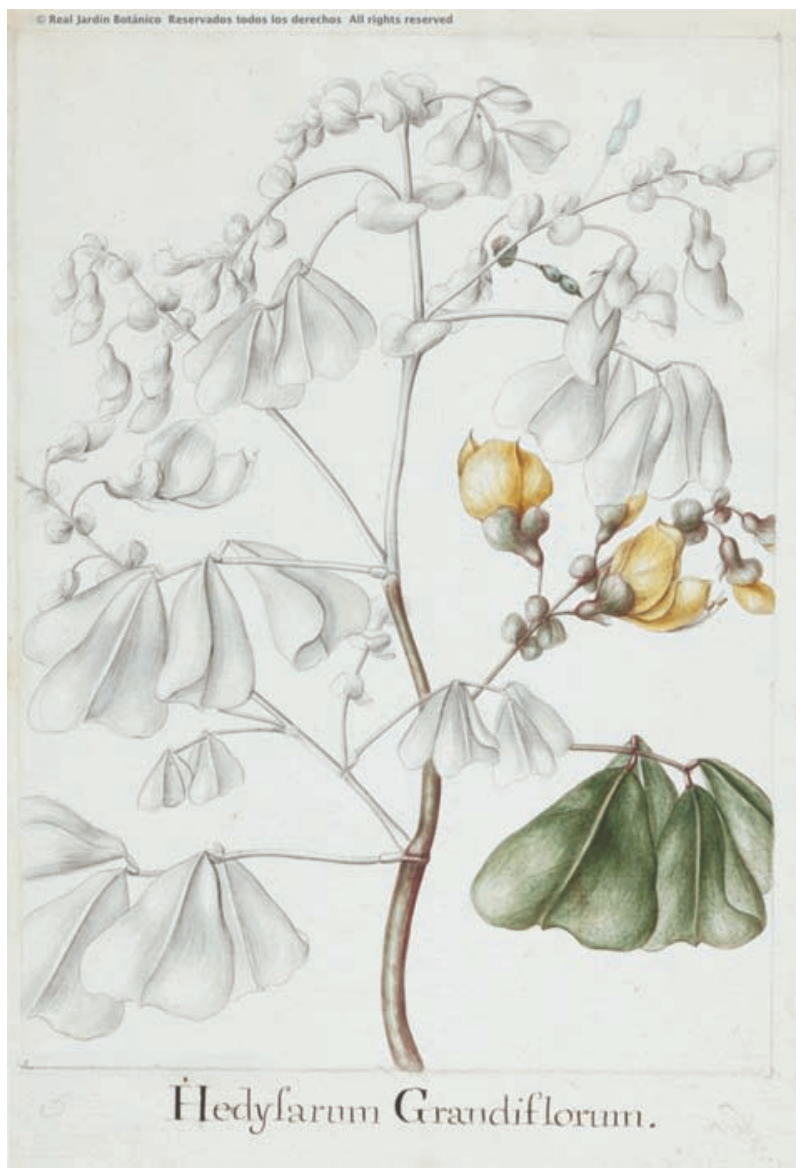

FIGURE 15. Hedysarum grandiflorum. Royal Botanic Expedition to New Spain (1787-1803). Archivo del Real Jardín Botánico

(CSIC), Madrid. Div. V, 99. Reproduced with permission.

artistic results of this enlightened company. Despite being very well considered by Commander Alejandro Malaspina, he was also often cautioned for his "lazy" work, which finally resulted in him being ordered to return back to Spain from the port of El Callao. In the end it did not happen like this, as José del Pozo was a friend of the Viceroy he founded a school of painting in Lima despite his family waiting for him in Seville. We know that in those years he devoted himself to making portraits for the Lima nobility, doing religious paintings, landscapes, etc., always following the principles of the Seville School which was very influenced by Murillo, until he died in la Ciudad de los Reyes in 1821 (Álvarez G., 2010) (figure 19).

Another painter also very well-known many years later for his involvement in various exploration adventures was José Guío y Sánchez, a Madrid native who was directly approached by Minister Valdes and offered a post, shortly before the expedition left Spain, as a painter of plants and expert in the dissection of birds and four-footed animals. Antonio Pineda widely recommended him to be hired as a botanical artist and dissector and to be a part of the staff of la Atrevida. His work was highly praised by the naturalists,

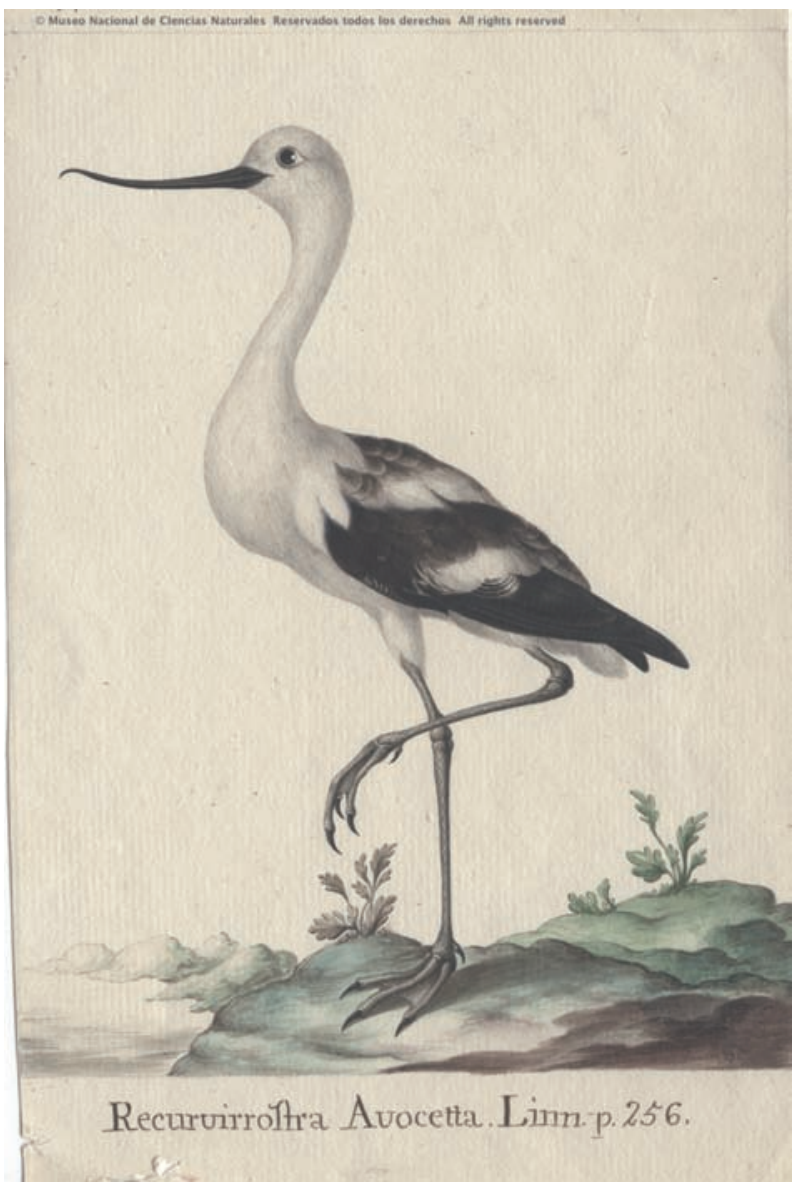

FIgURE 16. Recurvirrostra avoceta. Royal Botanic Expedition to New Spain (1787-1803). Museo Nacional de Ciencias Naturales (CSIC). Madrid. ACN110B/04741. Reproduced with permission.

especially by Pineda and Nee, but still Malaspina, who wanted less skilled painters, discharged him to Mexico after an intense job drawing animals and plants and dissecting hundreds of animals, until falling ill because of the scorching climate of the hot Mexican land. He eventually returned to Spain in 1791 on board a merchant ship, to be in charge of looking after the natural history collections in Madrid. The reality was that he had virtually no work until his recruitment as a painter of the expedition of the Earl de Mopox to Cuba in 1796 and was later praised for his collaboration with wise Cavanilles in the elaboration of his work 'Hortus Matritensis', which shows an indisputable technical perfection (figure 20).

Next we look at the two Italian painters hired by Malaspina for his company, who were always well considered by the Commander. The first of these is John Ravenet y Bunel, son of Juan Francisco Ravenet, Professor of engraving at the Academy of Fine Arts in Parma, which without a doubt influenced our painter and he would excel as a portrait painter. Both his and Malaspina's family maintained a close friendship, which led to Malaspina's recommendation for his 


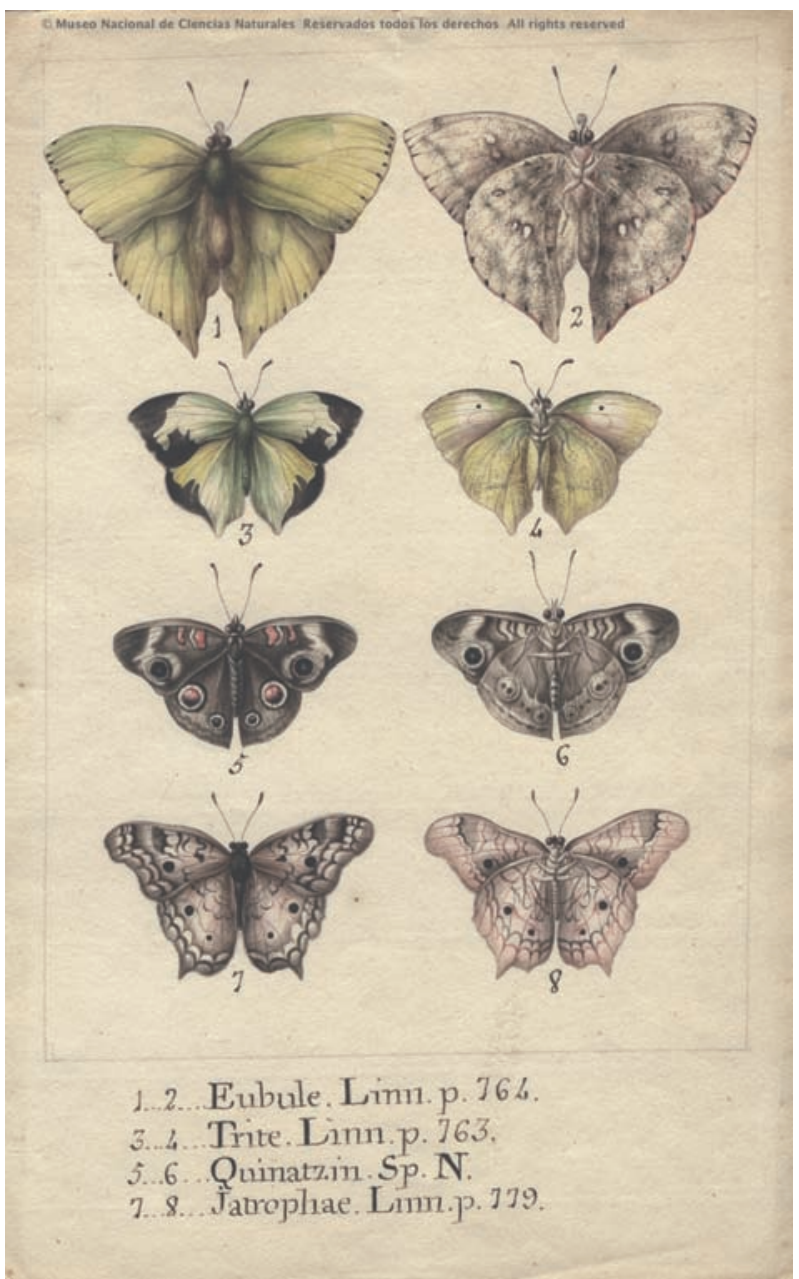

FigURE 17. Eubule Linn. Royal Botanic Expedition to New Spain (1787-1803). Museo Nacional de Ciencias Naturales (CSIC).

Madrid. ACN110B/04714. Reproduced with permission.

recruitment, but finally only the circumstances of José del Pozo leaving brought out him joining the expedition with the help of the Italian Ambassador in

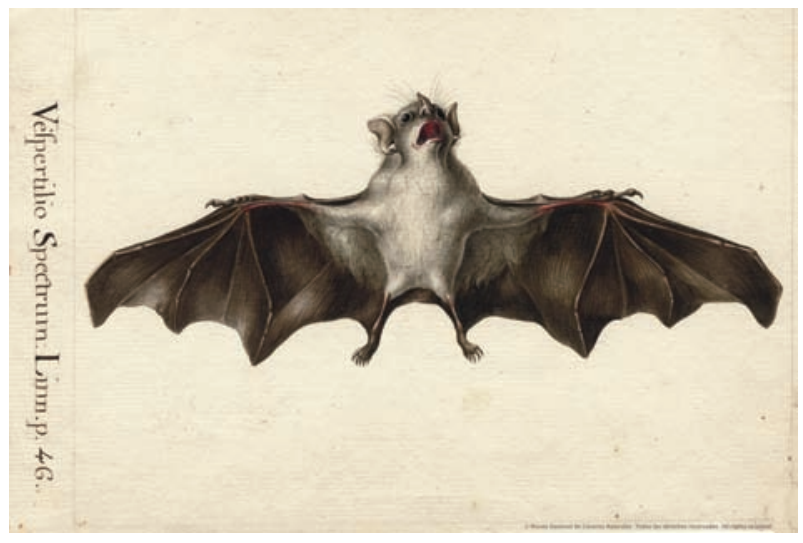

Figure 18. Vespertilio. Royal Botanic Expedition to New Spain (1787-1803). Museo Nacional de Ciencias Naturales (CSIC) Madrid. ACN110B/04742. Reproduced with permission.

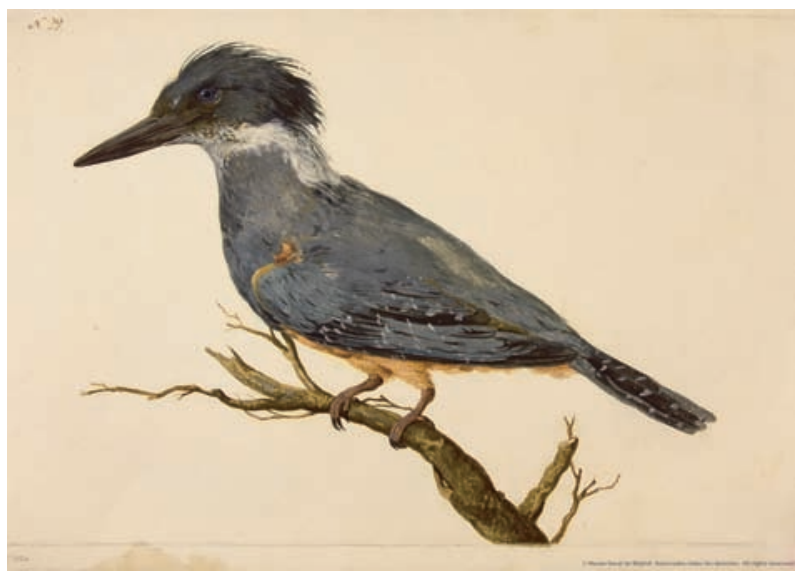

Figure 19. Kingfisher. José del Pozo. Malaspina Expedition (1789-1794). Museo Naval, Madrid. 1725 (76). Reproduced with permission.

Spain, who also took care of hiring another Italian painter Fernando Brambila with the intention of sending him to join the expedition when it stopped over at Acapulco. On his return to Madrid, he was put in charge of preparing drawings later to be passed on to be engraved with the help of a professor at the Academy of Fine Arts of San Fernando, jobs which he remained doing until the turbulent years of the Napoleonic invasion.

Fernando Brambila undoubtedly conquered the heart of Malaspina and later the Madrid Court for his perfection in landscape painting. At the time of hiring he was 28 years old and living in Milan, where he was already well-known as a painter. As we have already indicated he joined Ravenet in Mexico and from the outset he was recognized for his technique and artistic conception. Like his countryman, on his return to Madrid he continued in the King's service to finish the artwork, while also making others such as a view of the aqueduct of Segovia dated 1798. A year later he was appointed, as he had wanted, painter, architect, and decorator of the Royal Chamber for his

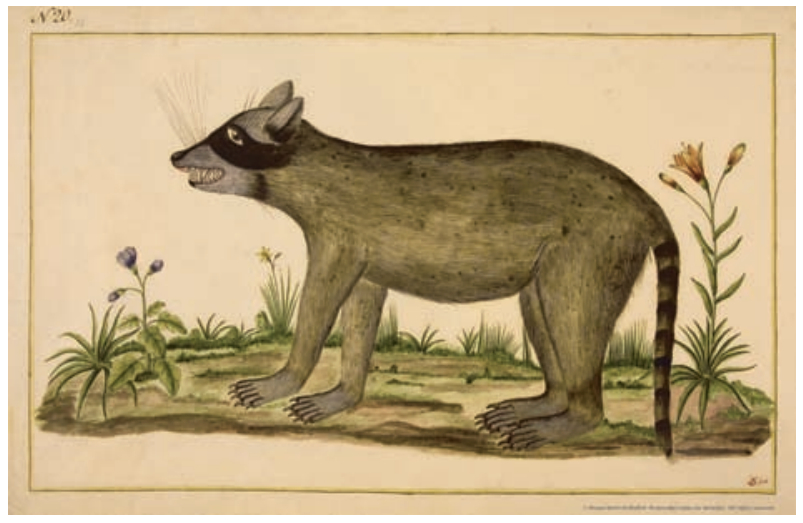

FIGURE 20. Raccoon. José Guío. Malaspina Expedition (17891794). Museo Naval, Madrid. 1726 (15). Reproduced with permission. 
artistic merits and work for the Crown, concluding in 1806. As court painter he worked in Toledo, Zaragoza during the war and was in Cádiz until in the end he joined the Academy of San Fernando as Professor. He became very well-known for his views of the Royal Sites where he worked until his death in Madrid in 1834 (figures 21 and 22).

Other painters also played a role in the Malaspina expedition although in a more circumstantial way. Among them we name first the Sevillan Jose Cardero Meléndez, who embarked in Cadiz as a simple sailor on la Descubierta and who developed his love for painting during the journey. His first drawing seems to be one of the Sacramento Colony and in Guayaquil he had already carried out some jobs as an artist of natural history and some scenes, before the Italian painters joined. Later he would be recognised as an artist and his drawings of Nootka would become wellknown, going there on two occasions as a year after Malaspina's visit he went on the Commission run by Cayetano Valdés to examine the Straits of Juan de Fuca with the schooners Sutil y Mexicana. On his return to Madrid he reviewed the work of this latest commission and shortly afterwards he was appointed ship's Purser destined to Cádiz, where finally his trail was lost (figure 23).

The painter who most influenced Cardero was undoubtedly Madrid's Tomas de Suria Lozano, trained also in the Academy of San Fernando and then moved to Mexico to found a school of engraving and work for the Royal Mint. Pozo leaving the exhibition was also the reason for him being recruited as an expert from the Royal Academy of San Carlos in Mexico, skilled in assessment and painting. He joined in Acapulco and was immediately made available to Antonio Pineda to do drawings of fish and other animals, although he later did some interesting ethnological character portraits. After finishing the expeditionary mission, Suria rejoined the Mexican Academy as Staff Writer, work to which he devoted the rest of his life. Francisco Lindo and Jose Gutierrez came from the same academy, occasionally collaborating with the expedition when José Guío was ill in Mexico.

A special case was the Czech naturalist Tadeo Haenke, who sometimes did botanical drawings, mining technique drawings and ones with an

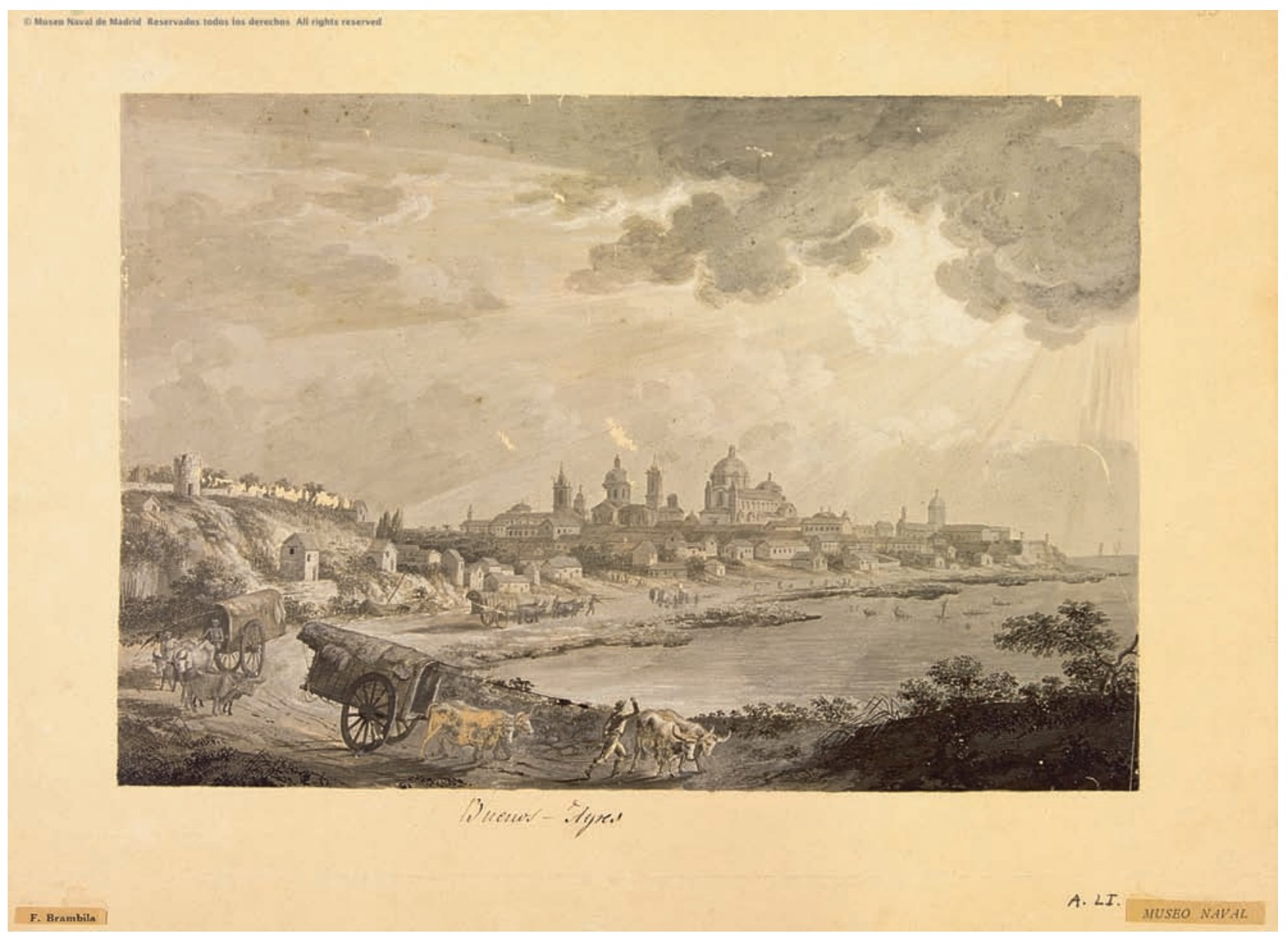

Figure 21. View of Buenos Aires. Fernando Brambila. Malaspina Expedition (1789-1794). Museo Naval, Madrid. 1726 (55). Reproduced with permission. 


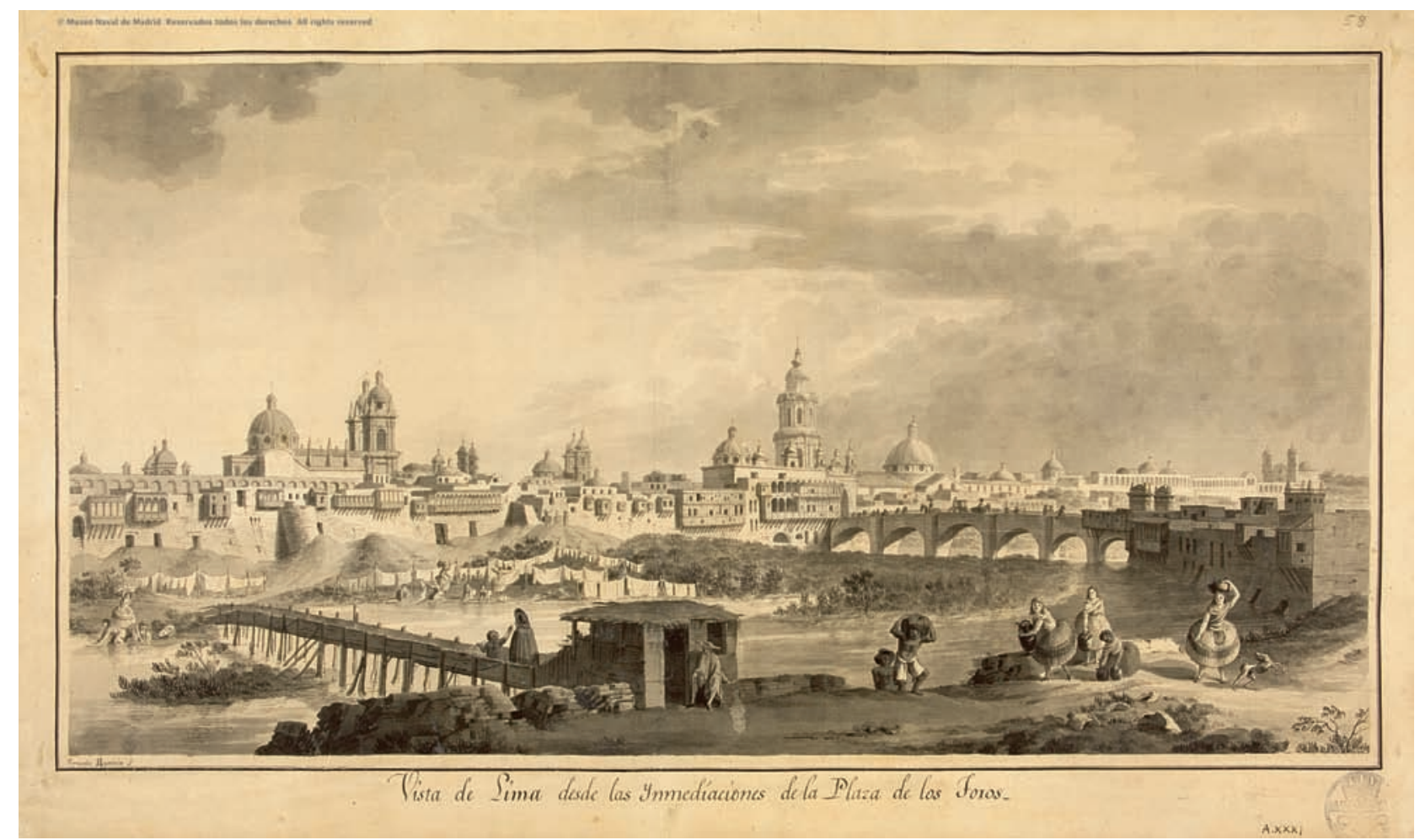

FiguRE 22. View of Lima from the bullring surroundings. Fernando Brambila. Malaspina Expedition (1789-1794). Museo Naval, Madrid. 1726 (58). Reproduced with permission.

ethnographic character. His colour chart has recently been studied which was found among his papers in the Royal Botanical Gardens, it seems to be an extension of the one used by the brothers Ferdinand and Franz Bauer showing 1000 tones of colours, known as the Feldsberg Chart, to which Haenke added a colour scale numbered up to the 2487. It seems that Haenkefue's Colour Chart was little used and remained almost just an academic exercise impractical for an expedition, although a sheet dedicated to the Tradescantia genre that has been found noting the key chart. (Mabberley and San Pío, 2012)

\section{THE VIEWS OF THE WORLD: MONTEVIDEO TO NEW ZEALAND}

One of the contributions of the Alexander Malaspina and José Bustamante expedition (1789-1794) to the world of art was their "scenes" of cities and territories in some iconographic depictions which gave an impression of the observed world in totality, although obviously developed differently depending on the painter and the technique employed. This did not just apply to the professional painters, since for example Felipe Bauzá appears as one of the authors of some sketches of these views. Without going further, one of the first drawings of Montevideo is by this cartographer, who depicts the city from the sea in a very simple pencil and ink sketch of great quality, although it is incomparable to Brambila's drawing 'Montevideo desde la aguada', a beautiful panorama of the city prepared by the Italian painter for engraving. In the same style but of lesser quality is Jose Cardero's wash drawing of Sacramento Colony, also done from the sea giving a panoramic view of the city or those of Buenos Aires by Brambila, this time from the river, or of Manila and Macau, giving the impression of line in the panorama or the perspective of the city, a kind of illustrated skyline, similar in conception to Felipe Bauzá coast lines.

The contrast would be José del Pozo's views of Puerto Deseado, Brambila's views in the Falklands or Ravenet's in Puerto Deseado, where the civilized city view is replaced by the impression of solitude in the confines of the world, or those of la Atrevida in trouble between the ice banks, although without the drama of William Turner. Halfway between the two would be Brambila's drawing of Talcahuano, José del Pozo's in Valparaíso or Cardero's in Guayaquil and Panama, made with a similar perspective to the first, but with an uneven result. We also find views produced with double authorship such as views of houses in the Andes or the Inca bridge by Brambila, actually drawings finished from Bauza's notes taken on his Andean mountain range passage accompanied by José Espinosa. There are doubts about the view of la Mocha in the Chilean city of Concepción, but everything points to a retouched drawing by Bauzá 


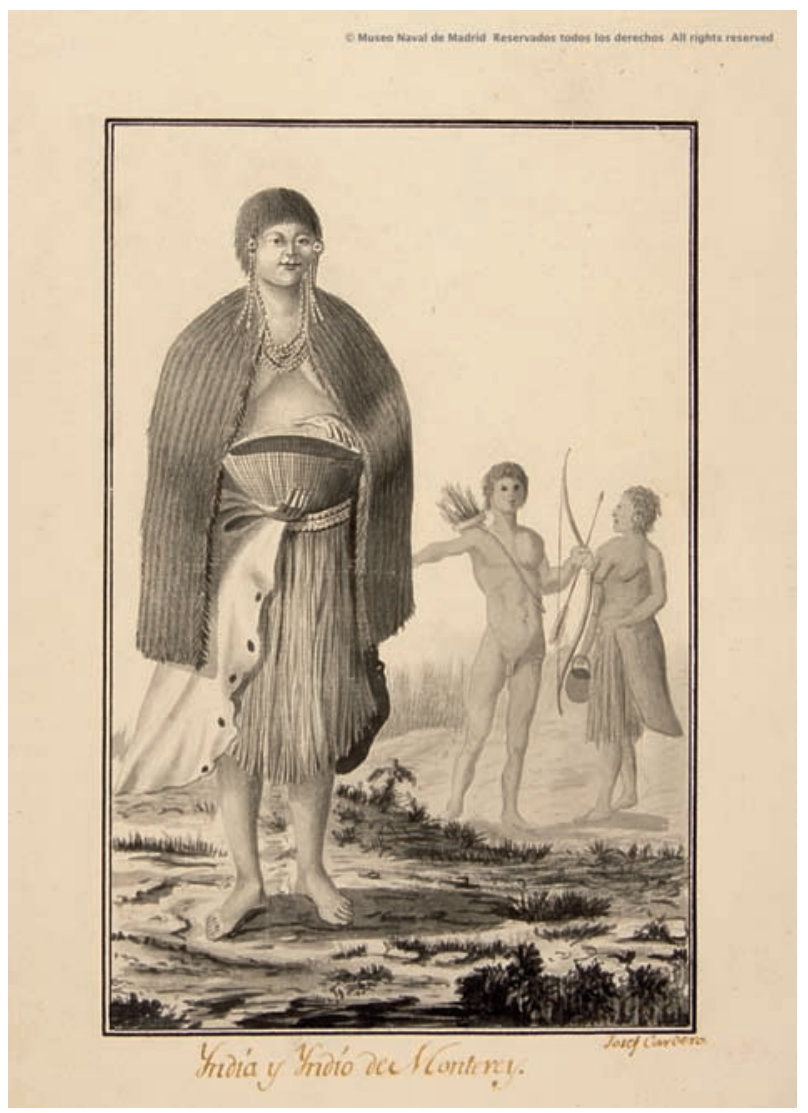

Figure 23. Male and female Indians from Monterrey. José Cardero. Malaspina Expedition (1789-1794). Museo Naval, Madrid. 1725 (3)-1. Reproduced with permission.

attributed to Pozo. There are also similarities between Bauza's view of Santiago de Chile from Santo Domingo hill and one by Brambila, although the second is obviously much more finished, something which happens again with the view of Santiago where the Mapocho River is observed in the foreground.

In any case Brambila's paintings of scenes acquire a great perfection, especially compared with his peers, and for example in his views of Lima, especially $E l$ paseo del Agua, the technique and colour is excellent, showing a style that he then continued in his Madrid paintings of royal sites. The contrast would be found in Cardero's drawings in Panama, El Realejo, or the Taboga islands, which were much less technical. The clearest examples are the Acapulco scenes by both painters, although we could also include Suria's, and the Mexico City scenes. A special case to compare the expedition painters' work is Gutierrez's depiction of Querétaro and its waterfall, since his style, in opposition to Brambila's classicism, is surprisingly "modern" mimicking the city with the basaltic columns, which results in a proto-Cubist scene hard to imagine in the illustrated painting (figure 24).

Brambila will also bring landscape elements to his scenes which Humboldt demanded in his Cosmos chapter; not to deal just with depicting the plant, animal or man in isolation but to form a whole which will shape a visual panorama corresponding to a place or latitude on the planet. We can see these pictorial features in use in his drawings of Guam Island, depicted as a lush tropical paradise, in some American or Australian scenes, and in some non-urban Philippines or Vavao ones (figure 25).

\section{THE ILLUSTRATED DEPICTION OF THE NATURAL WORLD}

In the botanical case, José Guío was the main architect of carrying out drawings, often connected with Luis Née's descriptions, giving them added value in the eyes of scientists. In general they were coloured wash drawings, sometimes drawn in their natural environment, depicting the plant from the root with its flowers and fruits and its floral layouts, trying always to create a "type" which would be realised as a new species. He also drew some animals in Mexico, from the axolotl, whose anatomy he left out, to others that were rare to the European world such as the opossum, raccoon or some birds and insects. We do not count others, as authorship is doubtful, depicting armadillos, light parrots, alligators, manatees, turtles, monkeys, etc. After Guío, another painter devoted to the plant world with greater dedication was Francisco Lindo, author of more than 70 often unfinished watercolours, but almost always with accurate botanical information for subsequent identification.

José del Pozo also widely depicted the animal world with drawings of American fish, birds, squirrels, pumas or opossums, although with very uneven artistic finishes, from a poorly sketched Great Crested Grebe to other very good works such as the kingfisher or the ibis. The self-taught José Cardero played a comparatively much better role, he did a good collection of bird drawings which included sea swallows or terns, trupials, jacanas, ovenbirds, herons, black-winged stilts, etc., also fish like the marlin, triggerfish, sea perch, roncador cay or the carangidae, or curious and sometimes unknown animals such as the light parakeet, lizards, iguanas, turtles, whose anatomy he drew, salps, jellyfish, caterpillars or the seahorse. Tomás Súria also participated in this kind of zoological drawings, always in the service of the naturalists, from whom we find a series of fish drawings, some birds and a coati of little artistic value, this is contrasted to Brambila's only three drawings in the Philippines, one depicting a sea cow in two positions and the other a bottlenose dolphin (figure 26).

\section{THE ANTHROPOLOGICAL TYPES: PATAGONIANS, MESTIZOS, INDIANS AND AUSTRALIANS}

Another of the values of the Malaspina expedition art collection was the collected images of the 


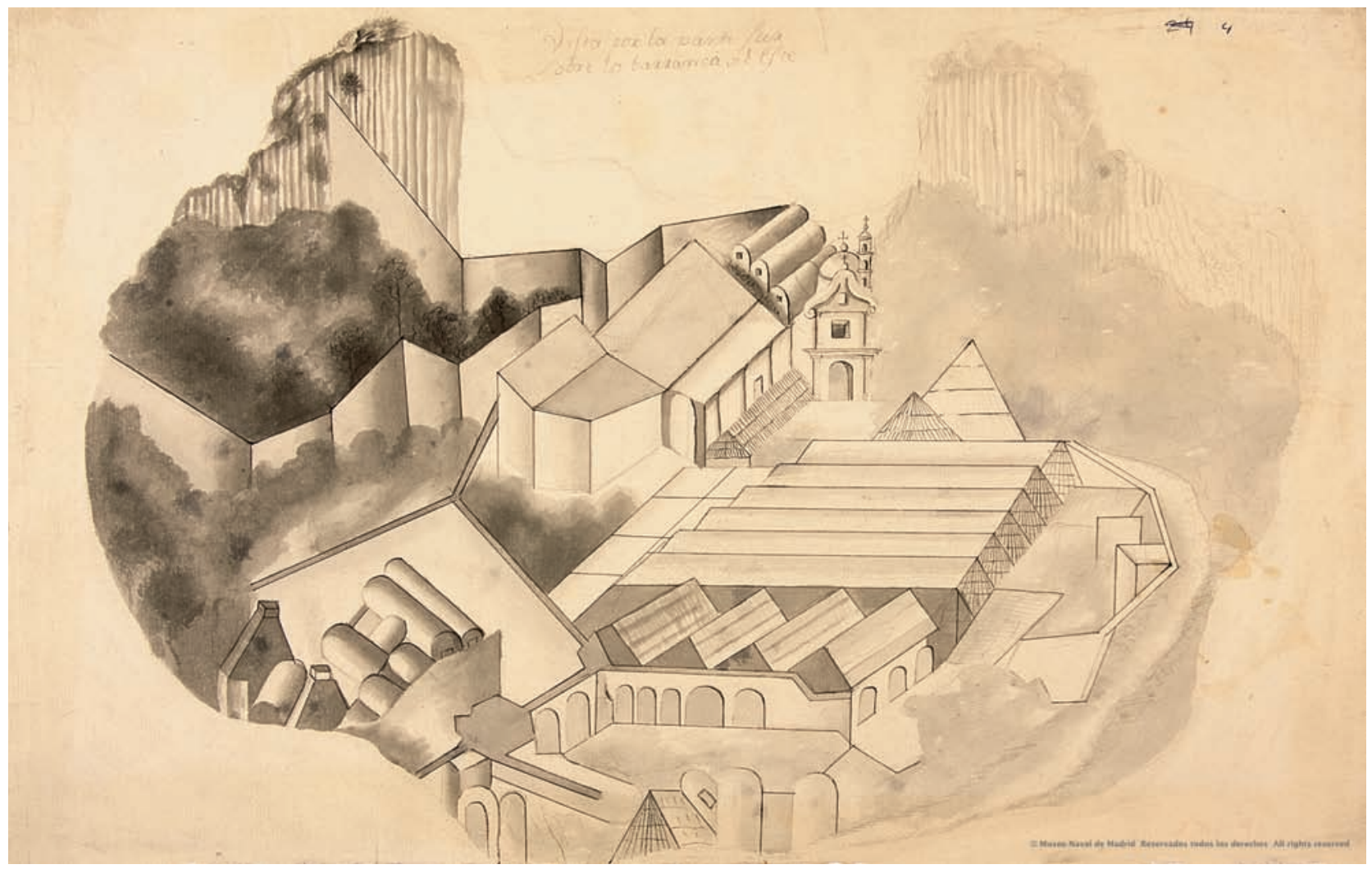

FigURE 24. Querétaro. José Gutiérrez. Malaspina Expedition (1789-1794). Museo Naval, Madrid. 1723 (27). Reproduced with permission.

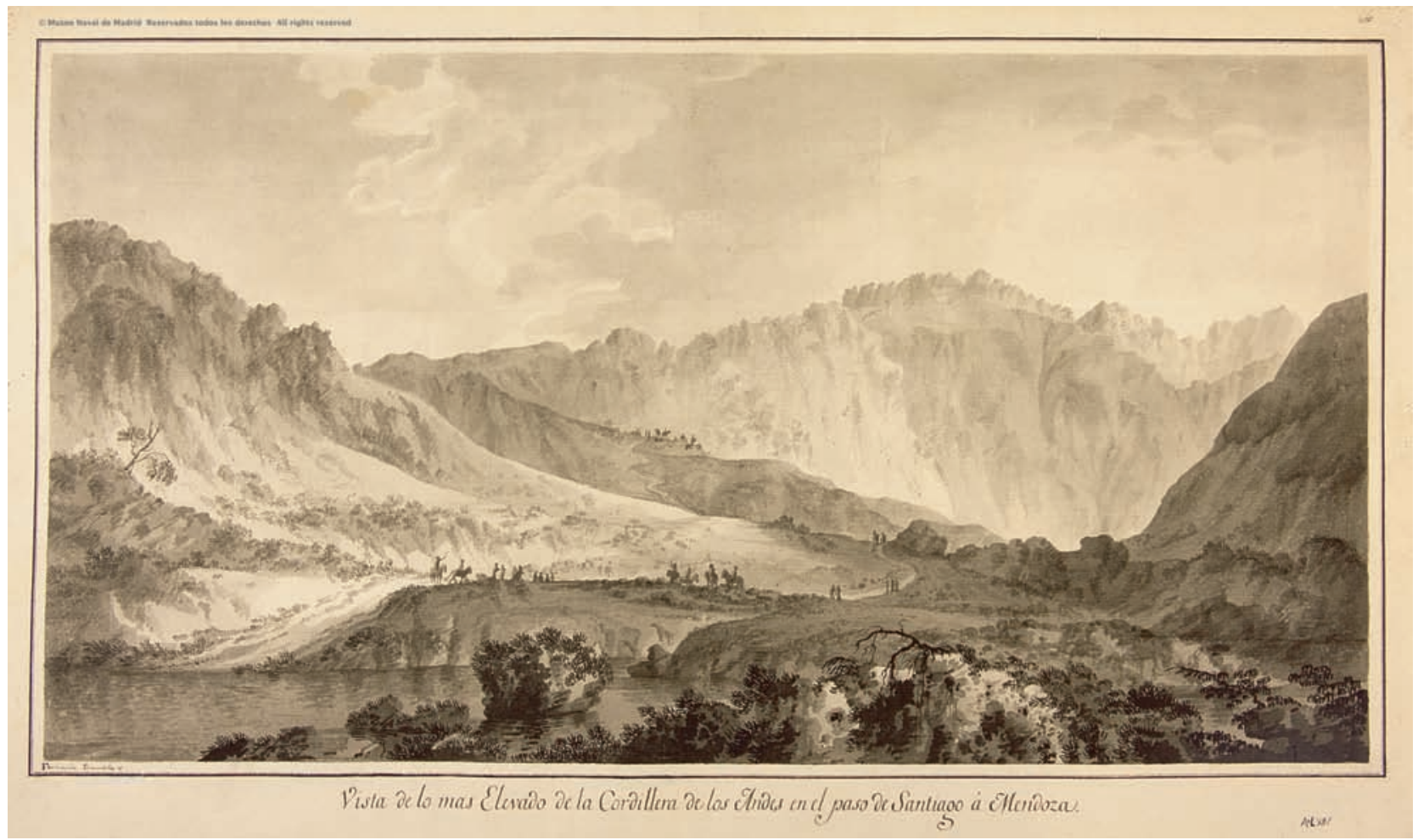

Figure 25. View from the top of the Andes at the Pass from Santiago to Mendoza. Fernando Brambila. Malaspina Expedition (1789-1794). Museo Naval, Madrid. 1726 (66). Reproduced with permission. 


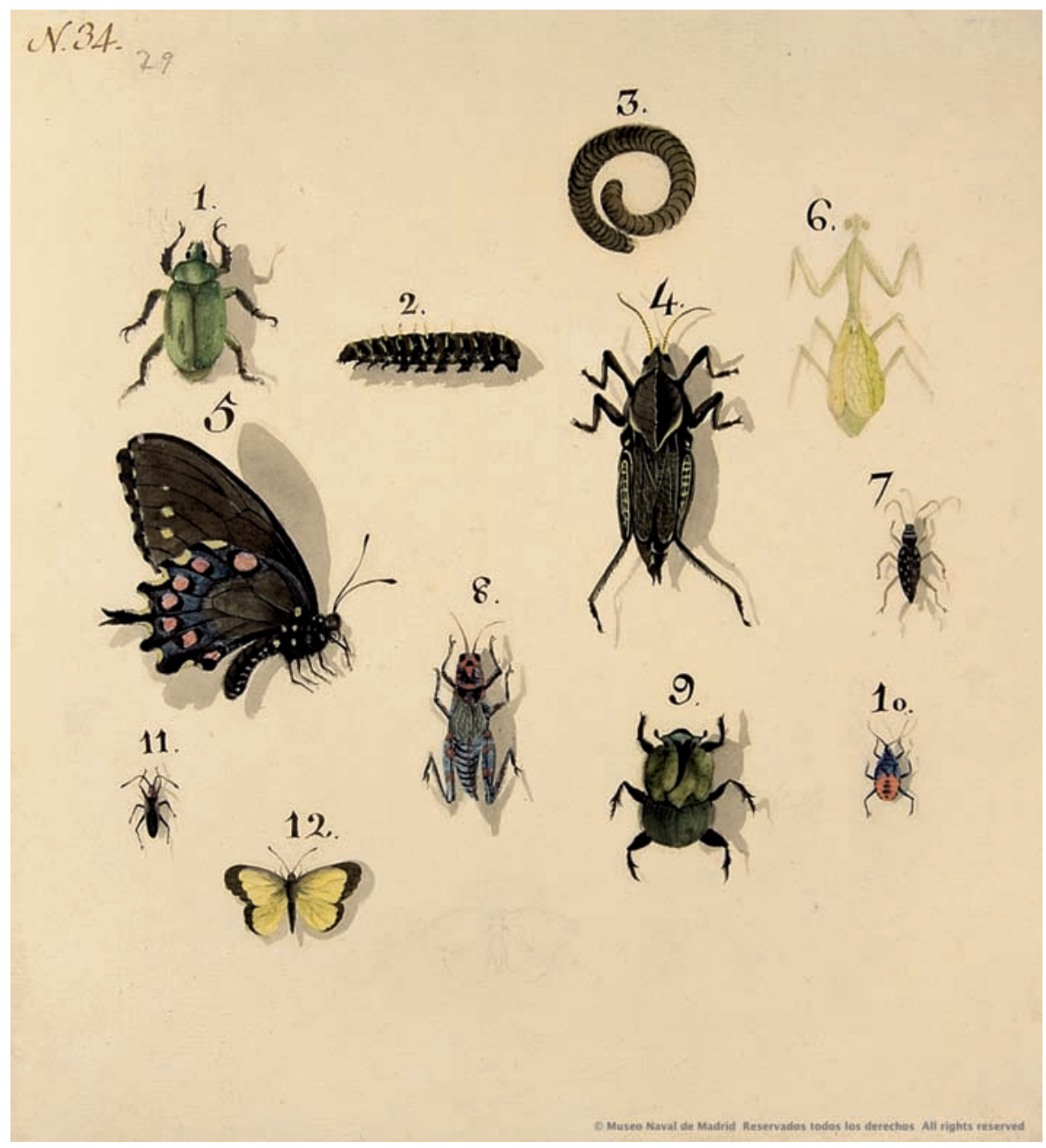

Figure 26. Insects. Malaspina Expedition (1789-1794). Museo Naval, Madrid. 1726(29). Reproduced with permission.

inhabitants of the worlds they visited, as their contemporaries also did and the romantic traveller painters did more intensely a few years later. The depictions will have therefore the seal of the American societies, the exotic islands of the Pacific, the Philippine Islands and the distant newly colonized territories of the New Netherlands and New Zealand.

From the "civilized" world of the Río de la Plata we only have the portrait of some ladies of Montevideo attributed to Ravenet, although logically it had to have been the work of another expeditionary since this painter had been in Mexico. Attracting much more attention is the mythical world of the Patagonian "Giants" by Pozo which are a group of very interesting drawings where Pozo himself is depicted drawing as well as the naturalist Pineda; the wild and the civilized in the same image, something that we have already seen in Requena's drawings and which happens frequently in the French and English expeditions. It is precisely this image of the marine scientist as Enlightened Spain's highest representative which appears in Ravenet's drawing done in Port Egmont, depicting Malaspina and Bustamante doing the gravity experiment, one of the crucial experiments for enlightened science that was done in the midst of the semi barbaric.

Contact with the Huiliche Indians is evident in Pozo's drawings in which the chief Catiguala and his son appear with a fine academic expression which contrasts somewhat with the sketch of Felipe Bauzá, who however depicted the Creoles as very European, although with an American "air". Along the same lines as Pozo we find Ravenet's drawings of a native Indian from Renquelque and a Cambayon Indian, as well as the portrait of the "authentic inhabitants of the Peru", the native Indian or the mountain Peruvian. We also find in this series of drawings some more traditional folk ones such as those by Suria about cockfighting in Acapulco, by Ravenet depicting a Mexican 'pulcheria' bar, a bath-house and the market of Manila or by Cardero and Brambila of ethnographic views of Mulgrave port, they are complemented by Cardero and Suria's portraits of the indigenous people of this same place. In the same style we can see the 
beautiful views of Nootka, representing the local customs, portraits of indigenous peoples and Chief Macuina by Suria, Bauza and Cardero, the latter being the painter of other magnificent portraits of the Chiefs the Northwest Coast and their wives. In the Philippine Islands' case, Ravenet would paint most of these ethnographic and traditional folk portraits of the inhabitants of the archipelago, from Creole women to the Filipino women, the Chinese or the negritos of the mountains of Manila. The same painter painted portraits of the Australia natives, which contrasted greatly with Bauza's drawings depicting the English and the New Netherland convicts.

With a classic feel, there is a drawing by Ravenet depicting a woman in a hammock which the Commander in Vavao used in order to laugh at Chief Vuna who was very fond of female company. Malaspina, who enjoyed the situation, tells us:

\footnotetext{
"Don Juan Ravenet, in one of those moments when the Navigator's oppressed spirit and the painter's always changing mind necessitated some relief and distraction, had occupied himself with depicting, with much decorum, a woman endowed with all the personal graces that we more commonly accept in our Europe, dressed, then, to imitate the Panamanian dames lying carelessly in a hammock, which formed a conjunction of images where we sometimes admired the lavish hand of nature and sometimes remembered the sad loneliness of the Navigator. Then he presented this painting to Vuna telling him that it was the portrait of one of our wives, similar to those of other officers, who did not come with us because we considered the work of the sea too sensitive for their delicacy; and so now we had to sail directly to the place where we had left them, with the just desire to not be separated from their amicable company again. Vuna immediately saluted it by the custom of touching noses, and then he examined her features one by one, her clothes and ornaments, and as she was understood by him his admiration and praise grew for the person depicted."
}

The Chief Vuna, while the expedition members laughed, proposed the idea of meeting her and exchanging several of his wives for the one in the picture, being prepared to accompany Malaspina, although on finding out he could only have one wife he dropped his attempt to meet the lady painted by Ravenet. Vuna, his wife Taufa and their son were drawn by the same artist, in an extensive series in which the indigenous people of Vavao were depicted in gentle images of "wild" tattooed men in a natural state of goodness, dancing or doing housework, while in one picture the Commander appears smiling accompanied by two native women combing his hair.

The conclusion on the results of Alexander Malaspina and José Bustamante's expedition is highly positive, if we take into account that they gave a new image of the world to the European world, after having developed a modern scientific and political project with a cooperative international scope and a high level team which set out ambitious objectives for Spain. The Malaspina expedition was a success in the two facets with which it had been commissioned: they returned with valuable scientific descriptions, put together large collections - 14,000 plants, 900 drawings and 500 zoological species - and mapped the coasts of all the Viceroyalties. The measurements of gravity to show the shape of our planet, new astronomical observations, geographical knowledge in the Atlantic and the Pacific, which gave rise to a new cartography, the opening of new navigation routes, the discovery of new plants, animals and minerals, as well as its own artistic and scientific representation helped generate, together with the contributions of other powers such as England or France, the new image of the enlightened world. A world much more globalized and visually perceived in the European imagination thanks to these icons and scenes drawn by the artists who accompanied the great expeditions of the Age of Enlightenment. Without a doubt, they paved the way for the romantic painting of the new century theorised by Alexander von Humboldt in his Cosmos.

\section{ACKNOWLEDGEMENTS}

Parts of this paper are the result of the project HAR2010-21333-C03-02, financed by the Ministry of Economy and Finance, Spain.

\section{NOTES}

1. Ms. 3357 from the Nacional Library of Spain, 7 vols.

2. Relación de premios, 1754 , pp. 30-31 y 39

3. General Archive of Simancas, State, leg. 7398, fol. 51.

4. Papel Periódico de la Ciudad de Santafé de Bogotá "El arcano de la quina revelado a benecio de la Humanidad", 10 May 1793/7 February 1794, Nos. 89-128, pp. 286-600. http:/www. banrepcultural.org/blaavirtual/historia/papel-periodico-de-santafe-de-bogota/indice.htm [accessed 24/September/2012]

5. Letter from Francisco Joseph de Caldas to José Celestino Mutis, Quito, 21st April 1803. Royal Botanical Garden Archive, Madrid (ARJB), III, 1, 1, 41.

\section{REFERENCES}

Álvarez, Raquel (1993) La conquista de la naturaleza americana. CSIC, Madrid.

Álvarez, Gabriela, S. (2010) “Las conexiones entre el pensamiento de Alejandro Malaspina y la representación visual de la expedición en la Patagonia (1789-1794)", Magallania, 38 (1) 5-18. http://dx.doi.org/10.4067/S0718-22442010000100001

Amaya, José Antonio (1986) Celestino Mutis y la Expedición Botánica. Debate. Madrid.

Amaya, José Antonio and Puig-Samper, Miguel Ángel (20082009) Mutis al natural. Ciencia y Arte en el Nuevo Reino de Granada. Museo Nacional de Colombia, Bogotá; Real Jardín Botánico, Madrid; Universidad de Valencia, Valencia.

Arias Divito, Juan Carlos (1968) La expediciones cientificas españolas durante el siglo XVIII. Expedición botánica de Nueva España. Cultura Hispánica, Madrid.

Barreiro, Agustín J. (1931) Relación del viaje hecho a los Reynos del Perú y Chile por los botánicos y dibujantes enviados para aquella expedición, extractado de los diarios por el orden que 
llevó en estos su autor D. Hipólito Ruiz. Real Academia de Ciencias Exactas, Físicas y Naturales, Madrid.

Beerman, Eric (1996) Francisco Requena. La expedición de límites: Amazonia, 1779-1795. Compañía Literaria, Madrid.

Bernabéu, Salvador (1994) Diario de las Expediciones a las Californias de J. Longinos, Doce Calles, Aranjuez.

Biographie Universelle ancienne et moderne (1843). Publiée sous la direction de M. Michaud, A. Thoisnier Desplaces Éditeur, Paris, XXIX: 658-662. http://http://gallica.bnf.fr/ark:/12148/ bpt6k516 [accessed 25/September/2012]

Blanco Fernández de Caleya, Paloma and del Valle, Ana (editors) (2009) Herbarium mutisianum. CSIC, Madrid.

Bleichmar, Daniela (2006) "Painting as Exploration: Visualizing Nature in Eighteenth-Century Colonial Science. Science and Nature in the Spanish Americas", Colonial Latin American Review, 15/1: 81-104. http://dx.doi.org/10.1080/10609160600 607499

Bleichmar, Daniela (2008) "El imperio visible: la mirada experta y la imagen en las expediciones científicas de la Ilustración", Cuadernos dieciochistas, Salamanca, 9: 21-47. http://campus. usal.es/ revistas_trabajo/index.php/1576-7914/article/view/7007/ 7017 [accessed 25/September/2012]

Burdet, Hervé M. (2000) "Relato de Augustin Pyramus de Candolle sobre la elaboración de la Flora de México, también conocida como Flora de las Damas de Ginebra". In El Águila y el nopal. La expedición de Sessé y Mociño a Nueva España (1787-1803), edited by de San Pío Aladrén, M. Pilar and PuigSamper, Miguel Ángel, Lunwerg, Madrid, pp. 93-104.

Blunt, Wilfrid and Stearn, William (1994) The Art of Botanical Illustration: An Illustrated History. Royal Botanic Garden, London.

Cavanilles, Antonio José (1801) Anales de Historia Natural, 7-9: 290.

Chenu, Jeanne (1992) Francisco José de Caldas, un peregrino de las ciencias. Historia 16, Madrid.

Costa, M. de Fátima and Diener, Pablo (2000) "Viaje filosófico al interior de la América portuguesa. La expedición de Alexandre Rodrigues Ferreira (1783-1792)". Anales del Museo de América, 8: 123-146. http://dialnet.unirioja.es/descarga/articulo/1455987.pdf [accessed 25/September/2012]

Díaz Piedrahita, Santiago (1994) "Caldas y la Historia Natural”. In Caldas, 1768-1816. Francisco Joseph de Caldas y Thenorio, edited by Arboleda, Luis Carlos and Díaz Piedrahita, Santiago, Molinos Velasquez Editores, Bogotá, pp. 111-123.

Flores Olvera, M. Hilda; Godínez Ortega, José Luis; Chiang Cabrera, Fernando; Vargas Valencia, Aurelia and Montemayor Aceves, Martha Elena (2010) "Las ilustraciones de plantas y su importancia en el conocimiento de la flora de México". In La Real Expedición Botánica a Nueva España, edited by Jaime Labastida, vol. I,. UNAM-Siglo XXI, México, pp. 181-205.

Frías, Marcelo (1994) Tras el Dorado Vegetal. José Celestino Mutis y la Real Expedición Botánica del Nuevo Reino de Granada. Diputación Provincial, Sevilla.

García Sánchez, Yaiza (2011) Memoria del nuevo mundo: imágenes para grabar de la expedición botánica de Sessé y Mociño (1787-1803). Tesis doctoral Universidad Complutense, Madrid. http://eprints.ucm.es/14068/1/T33252.pdf [accessed 25/September/2012]

González, Beatriz and Amaya, José A. (1996) "Pintores, aprendices y alumnos de la Expedición Botánica", Revista Credencial Historia, Bogotá, febrero de 1996

González Bueno, Antonio and Rodríguez Nozal, Raúl (1996) "The Expedition to Peru and Chile (1777-1788): inventory of scientific production", Huntia, 9 (2): 107-132.

González Bueno, Antonio and Rodríguez Nozal, Raúl (2000) Plantas americanas para la España Ilustrada. Ed. Complutense, Madrid.

Hernández Alba, Guillermo (1983) Archivo Epistolar del Sabio Naturalista José Celestino Mutis, ICH, Bogotá.

Higueras, Dolores (editor), (1987-1999) La Expedición Malaspina, 1789-1794. 9 vols. Museo Naval-Ministerio de Defensa/ Lunwerg, Madrid.

Higueras, Dolores (editor), (1991) Cuba Ilustrada. La Real Comisión de Guantánamo. Lunwerg, 2 vols., Barcelona.

Humboldt, Alexandre and Bonpland, Aimé (1805) Plantae Aequinoctiales, Vol. I, Tome premier, Chez Levrault, Schoell et Comp., Paris. http://gallica.bnf.fr/ark:/12148/bpt6k971 [accessed 25/September/2012]

Lafuente, Antonio and Sala Catalá, José (1992) Ciencia colonial en América. Alianza, Madrid.

López Piñero, José M.; Glick, Thomas; Navarro, Víctor and Portela, Eugenio (editors) (1983) Diccionario histórico de la ciencia moderna en España. 2 vols., Península, Barcelona.

Lozoya, Xavier (1984) Plantas y luces en México. Ed. del Serbal, Barcelona.

Lucena Giraldo, Manuel (1991a) Laboratorio tropical. Monte Ávila-CSIC, Caracas.

Lucena Giraldo, Manuel (editor), (1991b) Francisco de Requena y otros. Ilustrados y bárbaros. Diario de la exploración de límites al Amazonas (1782). Alianza, Madrid.

Lucena Giraldo, Manuel and Pimentel, Juan (1991) Los "Axiomas políticos sobre la América” de Alejandro Malaspina. Doce Calles, Aranjuez.

Lucena Giraldo, Manuel and de Pedro, Antonio (1992) La frontera caríbica: Expedición de Límites al Orinoco. Lagoven, Caracas.

Mabberley, David J. and de San Pío Aladrén, M. Pilar (2012) Haenke's Malaspina colour-chart: an enigma. Real Jardín Botánico CSIC- Ediciones Doce Calles, Madrid.

Manfredi, Darío (1994) Alejandro Malaspina, la América imposible. Compañía Literaria, Madrid.

Maldonado Polo, J. Luis (1996) Flora de Guatemala de José M. Mociño. Doce Calles, Aranjuez.

Maldonado Polo, J. Luis (1997) De California a El Petén. El naturalista riojano José Longinos Martínez en Nueva España. Instituto de Estudios Riojanos, Logroño.

Maldonado Polo, J. Luis (2001) Las Huellas de la Razón. CSIC, Madrid.

Maldonado Polo, J. Luis and Puig-Samper, Miguel Ángel (2000) "La aventura ultramarina de Sessé y Mociño. La Real Expedición Botánica a Nueva España (1787-1803). In El Aguila y el nopal. La expedición de Sessé y Mociño a Nueva España (1787-1803), edited by de San Pío Aladrén, M. Pilar and Puig-Samper, Miguel Ángel, Lunwerg, Madrid, pp. 35-52.

Maldonado Polo, J. Luis and Puig-Samper, Miguel Ángel (2006) "An unpublished eighteenth century treatise on the birds of Colonial Mexico", Archives of natural history, 33 (1): 53-70. http://dx.doi.org/10.3366/anh.2006.33.1.53

McVaugh, Rogers (2000) "Los dibujos de la Real Expedición Botánica". In El Águila y el nopal. La expedición de Sessé y Mociño a Nueva España (1787-1803), edited by de San Pío Aladrén, M. Pilar and Puig-Samper. Miguel Ángel, Lunwerg, Madrid, pp. 105-116.

Monge, Fernando and del Olmo, Margarita (1998) Las "Noticias de Nutka" de José Mariano Mociño. Doce Calles-CSIC, Aranjuez.

Navarro-Sigüenza, Adolfo; Townsend Peterson, A.; Puig-Samper, Miguel Angel and Zamudio, Graciela (2007) "The Ornitology of the Real Expedición Botánica a Nueva España (1787-1803): an analisis of the manuscripts of José Mariano Mociño", The Condor 109, 4: 809-824. http://www.cooper.org/publications/ recent_Condors/109_4/109_4abs07.pdf [accessed 01/October/ 2012]

Nieto Olarte, Mauricio (2000) Remedios para el Imperio: Historia Natural y la apropiación del Nuevo Mundo. ICANH, Bogotá.

Nieto Olarte, Mauricio (2006) La obra cartográfica de Francisco José de Caldas, Universidad de los Andes, Bogotá.

Nieto Olarte, Mauricio (2007) Orden natural y orden social: ciencia y política en el Semanario del Nuevo Reyno de Granada. CSIC, Madrid.

Palau, Mercedes (1980) Catálogo de los dibujos, aguadas y acuarelas de la expedición Malaspina, 1784-1794, Ministerio de Cultura, Madrid.

Palau, Mercedes (editor), (1984) Viaje científico y político a la América meridional, a las costas del mar Pacifico y a las islas Marianas y Filipinas, verificado en los años de 1789, 90, 92, 93 y 94. El Museo Universal, Madrid.

Pedro, Antonio de (1999) El Diseño científico, siglos XV-XIX. Akal, Madrid.

Pelayo, Francisco (2003) "Las expediciones científicas francesas y su influencia en la España del siglo XVIII". In La Botánica al servicio de la Corona. La expedición de Ruiz, Pavón y Dombey 
al Virreinato del Perú (1777-1831), edited by Félix Muñoz Garmendia, pp.14-49. Lunwerg, Barcelona.

Pelayo, Francisco and Puig-Samper, Miguel Angel (1992) La obra cientifica de Löfling en Venezuela. Lagoven, Caracas.

Pérez Arbeláez, Enrique (1983) José Celestino Mutis y la Real Expedición Botánica del Nuevo Reino de Granada. ICH, Bogotá.

Peset, José Luis (1988) Ciencia y libertad. CSIC, Madrid.

Peset, José Luis and Puig-Samper, Miguel Ángel (1988) “La simbología del científico: José Celestino Mutis como arbitrista de la ciencia", Asclepio, XL-2: 177-185.

Pimentel, Juan (1998) La física de la Monarquía. Ciencia y política en el pensamiento colonial de Alejandro Malaspina (17541810). Doce Calles, Aranjuez.

Puerto Sarmiento, Francisco Javier (1988) La Ilusión quebrada. Botánica, sanidad y política científica en la España Ilustrada. Serbal-CSIC, Barcelona-Madrid.

Puerto Sarmiento, Francisco Javier (1992) Ciencia de cámara. Casimiro Gómez Ortega (1741-1818), el científico cortesano. CSIC, Madrid.

Puig-Samper, Miguel Ángel (1991a) Las expediciones científicas durante el siglo XVIII. Akal, Madrid.

Puig-Samper, Miguel Ángel (1991b) "La expedición de Sessé en Cuba y Puerto Rico", Asclepio, XLIII-2: 181-198.

Puig-Samper, Miguel Ángel (2007) "La Geografía de las plantas de Alexander von Humboldt: la construcción del conocimiento científico y la prioridad del descubrimiento". In Escrituras y reescrituras del viaje, edited by Oliver, José M.; Curell, Clara; Uriarte, Cristina G. and Pico, Berta. Peter Lang, Bern. pp. 435445.

Puig-Samper, Miguel Angel and Pelayo, Francisco (1995) "Las expediciones botánicas al Nuevo Mundo durante el siglo XVIII. Una aproximación histórico-bibliográfica". In $L a$ Ilustración en América Colonial, edited by Soto, Diana; Puig-Samper, Miguel Ángel and Arboleda, Luis Carlos. Doce Calles-CSIC-Colciencias, Madrid, pp. 55-65.

Puig-Samper, Miguel Ángel and Zamudio, Graciela (1998) "Un manuscrito inédito de la Real Expedición Botánica a la Nueva España", Asclepio, L-1: 251-254. http://asclepio.revistas. csic.es/index.php/asclepio/article/view/360/358 [accessed 01/ October/2012]

Puig-Samper, Miguel Ángel; Maldonado, J. Luis and Fraga, Xosé (2004) "Dos cartas inéditas de Lagasca a Humboldt en torno al legado de Mutis", Asclepio, LVI-2: 65-86. http://asclepio. revistas.csic.es/index.php/asclepio/article/view/53/55 [accessed 01/October/2012]

Quilley, Geoff and Bonehill, John (editors), (2004) William Hodges, 1744-1797: the Art of Exploration, National Maritim Museum-Yale University Press, London.

Río Sadornil, José Luis del (2003) "Don Francisco Requena y Herrera: una figura clave en la Demarcación de los Límites Hispano-Lusos en la cuenca del Amazonas (s. XVIII)". Revista Complutense de Historia de América, 29: 51-75. http:// revistas.ucm.es/index.php/RCHA/article/view/RCHA0303110 051A/28629 [accessed 01/October/2012]

Rodríguez Nozal, Raúl (1995) "El trabajo científico en la España ilustrada: la Oficina Botánica y la publicación de las Floras Americanas". In Flora Peruviana et Chilensis, I: LXXXIVCVII, edited by Ruiz, H. and Pavón, J. Doce Calles, Aranjuez.

Rodríguez Nozal, Raúl (2001) La Oficina de la Flora Americana (1788-1835) y la marginación del proyecto de las expediciones botánicas ilustradas. Editorial Complutense, Madrid.
Rodríguez Nozal, Raúl and González Bueno, Antonio (1995) “La formación de grabadores para las Floras Americanas: un proyecto frustrado". In De la Ciencia Ilustrada a la Ciencia Romántica, edited by Díez Torre, A. R. Doce Calles, Aranjuez. Madrid, pp. 325-343.

Ruiz, Hipólito (2007) Relación del viaje hecho a los reinos del Perú y Chile por los botánicos y dibujantes enviados por el Rey ..., CSIC-Catarata, Madrid.

Sáiz, Blanca (1992) Bibliografía sobre la expedición Malaspina y su entorno. El Museo Universal, Madrid.

Sagredo Baeza, Rafael and José Ignacio González Leiva (2004) La Expedición Malaspina en la frontera austral del imperio español. Centro de Investigaciones Diego Barros AranaEditorial Universitaria, Santiago de Chile.

Saladino García, Alberto (1990) Dos cientificos de la Ilustración hispanoamericana: J. A. Alzate, F. J. de Caldas. UNAMUAEM, México.

Sánchez, Belén; Puig-Samper, Miguel Ángel and de la Sota, José (editors), (1987) La Real Expedición Botánica a Nueva España. Real Jardín Botánico-Ed. Quinto Centenario, Madrid.

San Pío, M. Pilar and Puig-Samper, Miguel Ángel (editors), (2000) El Aguila y el nopal. La expedición de Sessé y Mociño a Nueva Españal. Lunwerg, Barcelona.

Sotos Serrano, Carmen (1982) Los pintores de la Expedición de Alejandro Malaspina, 2 vols., Real Academia de la Historia, Madrid.

Sotos Serrano, Carmen (1984) Flora y fauna cubanas del siglo XVIII. Los dibujos de la expedición del Conde de Mopox 17961802, Turner, Madrid.

Sotos Serrano, Carmen (1989) "La botánica y el dibujo en el siglo XVIII". In La Botánica en la expedición Malaspina, 1789 1794, edited by Higueras, Dolores, pp. 71-79. Turner, Madrid.

Stafford, Barbara M. (1984) Voyage into substance: Art, science and nature and the ilustrated travel account, 1760-1840. MIT Press, Cambridge Mass.

Taracena Arriola, Arturo (1983) La expedición botánica al reino de Guatemala. Ed. Universitaria, Guatemala.

Uribe Uribe, Lorenzo (1953) "La Expedición Botánica del Nuevo Reino de Granada: su obra y sus pintores". Revista de la Academia Colombiana de Ciencias Exactas, Físicas y Naturales, 19: 1-13.

Vega, Jesusa (2011) Ciencia, Arte e Ilusión en la España Ilustrada. Polifemo-CSIC, Madrid.

White, James; McVaugh, Rogers and Kiger, Robert W. (1998) The Torner Collection of Sessé and Mociño biological illustrations, Hunt Institute for Botanical Documentation, Carnegie Mellon CD Press, Pittsburg.

Wilson Engstrand, Iris H. (1981) Spanish Scientist in the New World. University Washington Press, Washington.

Zamudio, Graciela (2000) "Catálogo de los dibujos de la Real Expedición Botánica del archivo del Real Jardín Botánico de Madrid". In El Águila y el nopal. La expedición de Sessé y Mociño a Nueva España (1787-1803), edited by de San Pío Aladrén, M. Pilar and Puig-Samper, Miguel Ángel, pp. 117209. Lunwerg, Madrid.

Zamudio, Graciela (2010) "Los artistas y las ilustraciones de la expedición científica a Nueva España”. In La Real Expedición Botánica a Nueva España, edited by Labastida, Jaime, vol. I, pp. 135-155. UNAM-Siglo XXI, México. 